\title{
Concentrations, health risks, and sources of hazardous air pollutants in Seoul-Incheon, a megacity area in Korea
}

\author{
Min-Ji Kim ${ }^{1,2} \cdot$ Kyung-Min Baek ${ }^{1,3} \cdot$ Jong-Bae Heo $^{4} \cdot$ Jang-Pyo Cheong $^{5} \cdot$ Sung-Ok Baek ${ }^{1}$ (I)
}

Received: 24 October 2020 / Accepted: 13 January 2021 / Published online: 26 April 2021

(C) The Author(s) 2021

\begin{abstract}
We conducted ambient monitoring of various hazardous air pollutants (HAPs) for 2 years (2013-2015) in two adjacent Korean cities in a megacity area: Seoul and Incheon. Measured HAPs included volatile organic compounds (VOCs), polycyclic aromatic hydrocarbons (PAHs), and heavy metals (HMs). The objectives of this study were to evaluate the spatiotemporal variations of HAPs, to prioritize HAPs based on health risks, to identify sources using a receptor-based model, and to estimate source-specific risks. Overall, the HAP levels in Incheon were higher than those in Seoul. The concentrations of combustion-origin HAPs, such as PAHs and some HMs, were significantly higher during the heating period than during the non-heating period. However, most VOCs exhibited an opposite trend. Benzo[a]pyrene showed the highest cancer risk in both cities, followed by formaldehyde, arsenic, and benzene; trichloroethylene was the only species that exceeded the hazard quotient of 1 . Cumulative cancer risks were $2.0 \times 10^{-4}$ in Seoul and $2.7 \times 10^{-4}$ in Incheon. Major sources and their contributions to each HAP concentration were estimated by positive matrix factorization modeling. Based on source-specific risk assessments, we suggest that both cities should give high priority to the control of traffic pollution and the supply of cleaner fuels in non-residential sectors. Reducing carbonyl concentrations in Seoul and industrial emissions in Incheon is also necessary. Establishing new ambient standards for benzo[a]pyrene and formaldehyde is worth considering as a long-term measure. This study provides scientific information on the occurrence, health risks, and sources of various HAPs in large urban areas.
\end{abstract}

Keywords Megacity; · Polycyclic aromatic hydrocarbons; · Volatile organic compounds; · Heavy metals; · PMF modeling; · Risk assessment $\cdot$ Min-Ji Kim and Kyung-Min Baek both contributed equally to this work

\section{Introduction}

Air pollution is recognized as a public health threat and is an inevitable consequence of fossil fuel consumption for energy production and industrial activities (An et al. 2018; Samet and Gruskin 2015). East Asia is seriously affected by air pollution, particularly ambient particulate matter (PM) (Kim et al. 2018;

Sung-Ok Baek

sobaek@yu.ac.kr

1 Department of Environmental Engineering, Yeungnam University, Gyeongsan 38541, Korea

2 National Center for Fine Dust Information, Ministry of Environment, Cheongju 28166, Korea

3 Environment, Health and Welfare Research Center, Korea Institute of Science and Technology, Seoul 02792, Korea

4 Busan Development Institute, Busan 47210, Korea

5 School of Civil, Urban, and Environmental Engineering, Kyungsung University, Busan 48434, Korea
Park et al. 2019; Parrish and Zhu 2009). The association of environmental factors with cancer in humans (IARC 2018; USEPA 2019; WHO 2000) has focused attention on the adverse effects of hazardous air pollutants (HAPs, or air toxics) in urban and industrial areas (Kim et al. 2020; Scheffe et al. 2016; Wu et al. 2011).

There is no clear definition of HAPs; some characteristics of HAPs are (i) HAPs include many genotoxic and carcinogenic chemicals (WHO 2000); (ii) most HAPs are nonthreshold pollutants that affect health from prolonged exposure to low concentrations (Patrick 1994); (iii) some HAPs exert non-carcinogenic respiratory effects, environmental impact, and bioaccumulation (USEPA 2019). Toxic chemicals that are classified as HAPs include volatile organic compounds (VOCs), polycyclic aromatic hydrocarbons (PAHs), heavy metals (HMs), phthalates, dioxins/furans, and organochlorine pesticides (IARC 2018; USEPA 2019).

The lists of toxic substances or the groups of chemicals designated as HAPs vary from country to country, depending on regulatory, social, and industrial conditions. The US 
Environmental Protection Agency (USEPA) identified 187 air toxics under the Clean Air Act and defined 33 HAPs as urban air toxics (USEPA 2017). The Canadian Environmental protection Act listed some of the 187 HAPs named by the USEPA as "toxic substances" (Bari and Kindzierski 2017). The Japan Ministry of Environment listed 248 toxic chemicals as specific airborne hazardous substances and selected 23 of them as priority pollutants (Baek et al. 2020). The Korean Clean Air Act defines HAPs as specific air toxics that adversely affect the public by prolonged exposure to low concentrations. The list of HAPs in Korea expanded from 16 in 1978 to 35 in 2007. Because of these low numbers, the Korean policies for managing HAPs have been criticized as being inferior to those in the US and Japan (Kim et al. 2020).

In general, air pollutant emissions in densely populated urban areas (often called megacities) are high due to the density of traffic and intensity of energy use (Baklanov et al. 2016; Gulia et al. 2015). The environmental significance of urban air toxics is justified not only by the size of the exposed population but also by the diversity of emission sources relative to non-urban areas. Furthermore, continuous exposure to multiple toxics from stationary and mobile sources increases the public health risks. Risk assessment of urban air toxics is procedurally complex and requires a broad scope of data input. Consequently, monitoring HAPs in ambient air provides public exposure data that is crucial to the process.

Seoul is the largest and most densely populated city in South Korea, where approximately 10 million people inhabit only $0.6 \%$ of the total area $\left(100,210 \mathrm{~km}^{2}\right)$. Incheon is a port city west of Seoul and is the third-largest city in Korea, with a population of 3 million. Although Seoul and Incheon are separate administrative districts, they are adjacent to each other, forming a daily life zone. The two cities are referred to as the Seoul-Incheon Megacity Area (SIMA), where $25 \%$ of the Korean population lives. In Seoul, the number of industrial areas is small because, for the past 40 years, industries that produce pollution have been forced to move to the SihwaBanwol national industrial complexes (SBNIC), $\sim 30 \mathrm{~km}$ southwest of Seoul. As of 2015, the SBNIC comprised more than 10,000 businesses, and is one of Korea's largest industrial areas (Baek et al. 2019). In contrast to Seoul, many sources of air pollution exist within the territory of Incheon, such as ports, airports, industrial complexes, and power plants. In addition, residential areas are close to these industrial complexes and are downwind.

One objective of air quality management is to reduce health risks caused by air pollution (Gulia et al. 2015). Although effectively managing all toxic pollutants is virtually impossible, identifying and prioritizing the management of pollutants that pose the most significant risks to residents, particularly in megacities, is an effective approach to reduce health risks. Numerous studies on air quality have been conducted in Seoul during the last three decades. However, most of these studies focused on criteria pollutants (e.g., $\mathrm{SO}_{2}, \mathrm{NO}_{\mathrm{x}}, \mathrm{O}_{3}$, and PM), and few studies addressed issues related to HAPs (Kim and Lee 2018). Although several studies on VOCs (Na and Kim 2001; Na et al. 2002) and PAHs (Bae et al. 2002; Kim et al. 2013; Lee et al. 2011) have been conducted in Seoul, measurements were taken sporadically and were limited to a small number of toxic pollutants. In addition, the air quality in Incheon has been ignored. Therefore, comprehensive monitoring of a wide range of HAPs has been proposed as an important and urgent task to determine ambient concentrations and recommend measures for protecting public health (Kim and Lee 2018; Kim et al. 2018; Parrish and Zhu 2009).

In this study, we carried out an intensive monitoring project from 2013 to 2015 at seven sites in Seoul and Incheon; these sites represent typical non-industrial areas of each city. More than 100 toxic chemicals were measured at each site, including VOCs, PAHs, and HMs. The data were then used to identify the sources and to prioritize the HAPs that pose the greatest health risks. The specific objectives of this study were (i) to investigate the occurrence, concentration, and spatiotemporal variation of HAPs in the ambient air of Seoul and Incheon; (ii) to prioritize HAPs based on health risk assessments; (iii) to identify major sources of HAPs using positive matrix factorization (PMF) modeling; and (iv) to apportion the health risks into contributing sources.

\section{Materials and methods}

\section{Sampling periods, sites, and weather conditions}

Sampling was conducted in seven seasons over 2 years from 2013 to 2015. The monitoring protocols in the first and second years differed with respect to sampling location, period, and frequency. In the first year (from August 2013 to February 2014), samples were collected in three seasons (summer, autumn, and winter) at three sites in Seoul for ten consecutive days per season. In the second year (from July 2014 to March 2015), sampling was conducted at four sites in Incheon for seven consecutive days per season over four seasons. In Incheon, we added one additional sampling site in consideration of the city's topographical complexity and the diversity of emission sources. Since this study focused on the occurrence of HAPs in the ambient atmosphere exposed to the general public, the selection of sampling sites in each city was determined by considering the spatial distribution of nonindustrial areas. The location of each sampling site is shown in Fig. 1; details about the sampling periods in each year and the number of samples collected during the seasonal campaigns are presented in Table 1. Most air samples were collected on rooftops (10-15 $\mathrm{m}$ above the ground); one site was on a roadside. The details of the situation around each sampling site are described in Text S1 (Supplementary Materials). 
Fig. 1 Location of sampling sites in Seoul and Incheon (circles indicate locations of industrial complexes)
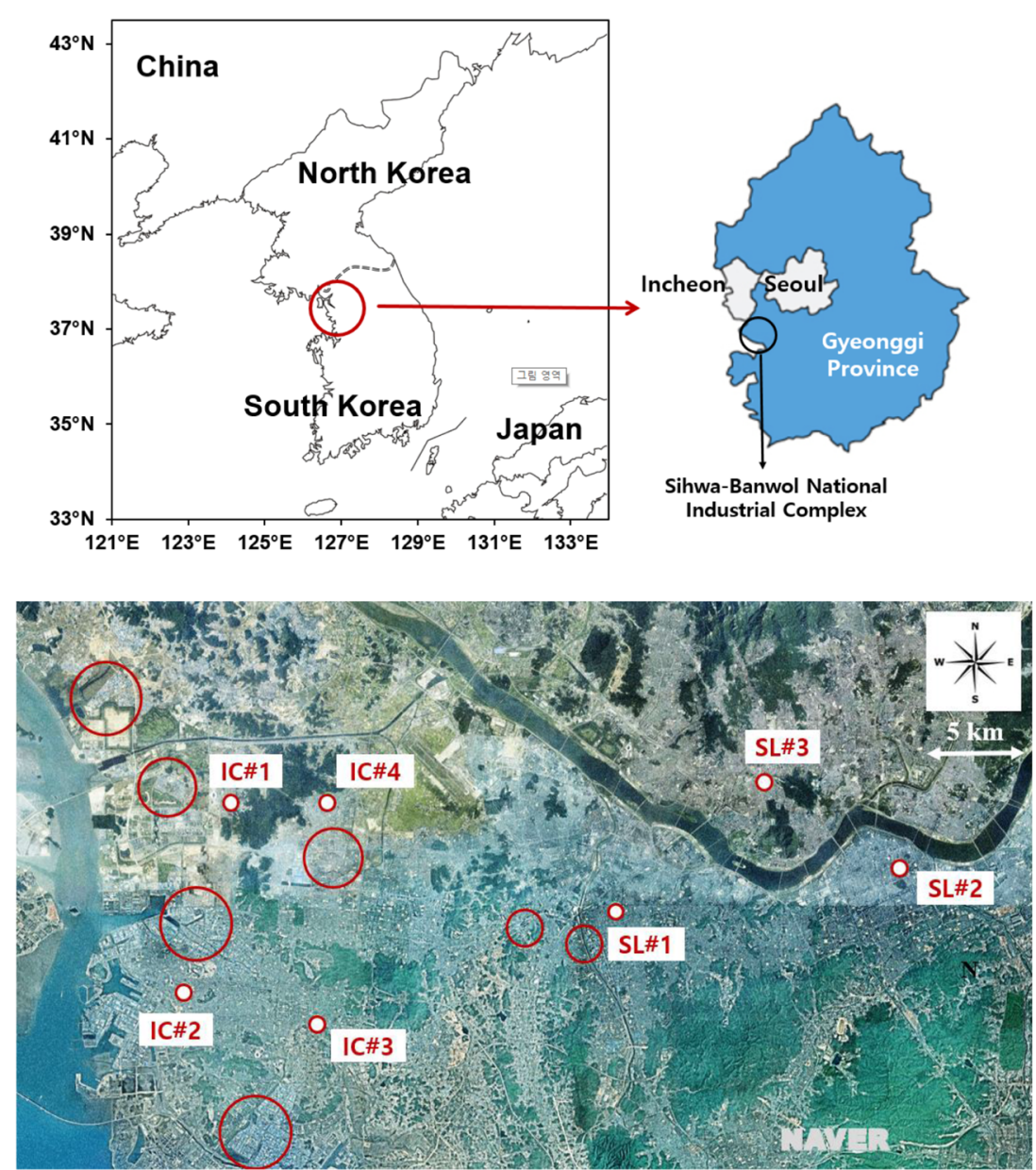

SL\#1: Guro5-dong (373' $\left.17.2^{\prime \prime N} 126^{\circ} 57^{\prime} 58.5^{\prime \prime E}\right)$ SL\#3: Dongja-dong (37²9'37.4"N 126 $\left.55^{\circ} 01.3 " \mathrm{E}\right)$ IC\#1: Yeonhee-dong $\left(37^{\circ} 33^{\prime} 18.0^{\prime \prime} \mathrm{N} 126^{\circ} 41^{\prime} 25.8^{\prime \prime} \mathrm{E}\right)$ IC\#3: Guwol-dong $\left(37^{\circ} 28^{\prime} 19.9^{\prime \prime N} 126^{\circ} 45^{\prime} 02.5^{\prime \prime E}\right)$
SL\#2: Samsung-dong $\left(37^{\circ} 30^{\prime} 48.2^{\prime \prime N} 127^{\circ} 02^{\prime} 49.2^{\prime \prime E}\right)$

IC\#2: Sungeui-dong (37³3'18.0"N 126 $\left.46^{\circ} 25.8^{\prime \prime} \mathrm{E}\right)$ IC\#4: Gyesan-dong (37²8'39.9"N 126³7'28.3"E)

Table 1 Sampling information and weather conditions during the HAP monitoring campaigns in Seoul and Incheon

\begin{tabular}{|c|c|c|c|c|c|c|c|c|}
\hline \multirow[t]{2}{*}{ Season } & \multirow{2}{*}{$\begin{array}{l}\text { Sampling period } \\
\text { (month/date) }\end{array}$} & \multirow[t]{2}{*}{ Sampling site } & \multicolumn{2}{|c|}{ Number of samples } & \multirow{2}{*}{$\begin{array}{l}\text { Temperature }\left({ }^{\circ} \mathrm{C}\right) \\
\text { Mean } \pm \mathrm{SD}\end{array}$} & \multirow{2}{*}{$\begin{array}{l}\text { Wind speed } \\
(\mathrm{m} / \mathrm{s}) \text { Mean } \pm \mathrm{SD}\end{array}$} & \multirow{2}{*}{$\begin{array}{l}\text { Prevailing } \\
\text { wind direction }\end{array}$} & \multirow{2}{*}{$\begin{array}{l}\text { Rainfall } \\
(\mathrm{mm})\end{array}$} \\
\hline & & & VOC & $\begin{array}{l}\mathrm{PAH} / \\
\mathrm{HM}\end{array}$ & & & & \\
\hline \multicolumn{9}{|l|}{ Seoul } \\
\hline 2013 Summer & $8 / 17-8 / 27$ & 3 & $60(54)^{*}$ & 30 & $27.8 \pm 2.5$ & $1.9 \pm 0.8$ & SE & 50.5 \\
\hline 2013 Autumn & $11 / 12-11 / 22$ & 3 & $60(60)$ & 30 & $4.8 \pm 2.0$ & $2.1 \pm 0.8$ & $\mathrm{~W}$ & 8.3 \\
\hline 2014 Winter & $2 / 4-2 / 14$ & 3 & $60(60)$ & 30 & $0.0 \pm 1.8$ & $2.2 \pm 0.8$ & NW & 3.4 \\
\hline \multicolumn{9}{|l|}{ Incheon } \\
\hline 2014 Summer & $7 / 30-8 / 5$ & 4 & $50(48)$ & 28 & $27.9 \pm 2.4$ & $1.7 \pm 1.0$ & $\mathrm{E}$ & 14.9 \\
\hline 2014 Autumn & $10 / 15-10 / 21$ & 4 & $56(40)$ & 28 & $15.0 \pm 2.6$ & $1.5 \pm 0.8$ & $\mathrm{~W}$ & 41.3 \\
\hline 2015 Winter & $1 / 13-1 / 19$ & 4 & $56(56)$ & 28 & $-0.5 \pm 2.0$ & $1.9 \pm 0.9$ & NW & 3.7 \\
\hline 2015 Spring & $3 / 18-3 / 24$ & 4 & $56(56)$ & 28 & $7.7 \pm 4.4$ & $2.0 \pm 1.2$ & NW & 1.5 \\
\hline
\end{tabular}

*Number in parenthesis indicates the number of carbonyl samples 
Hourly meteorological data during the sampling periods were obtained from the automatic weather stations in Seoul and Incheon, and the data are summarized in Table 1. Seasonal variations in the prevailing winds showed distinct patterns: SE-E winds in summer and NW-W winds in other seasons, indicating that this area is frequently affected by westerly winds blowing from the continent, particularly during cold seasons. Rainfall was observed in every sampling period, and a larger amount fell in summer than in other seasons, which is typical for South Korea.

\section{Measurement of vapor phase HAPs}

VOCs The VOC measurement method was based on the USEPA TO-17 protocol, which has been used in several field studies (Baek et al. 2015, 2020a, b; Kim, et al. 2020; Seo et al. 2014). VOCs were collected twice per day (09:00-12:00 and 14:00-17:00) by drawing air through a stainless-steel tube (0.6 mm x $9 \mathrm{~cm}$, Perkin Elmer, UK) packed with double sorbents: $120 \mathrm{mg}$ and $280 \mathrm{mg}$ of Carbograph-2TD and Carbograph-1TD (40/60 mesh, Markes, UK) in the front and back positions, respectively. The flow rate was set at $100 \mathrm{~mL} /$ min per sample using a personal pump (FLEC Air Pump 1001, Chematec, Denmark). The sampling flow rate and duration were selected to avoid any breakthrough phenomena with a margin of safety. VOC analysis was performed by thermal desorption (Unity/Ultra, Markes, UK) and gas chromatography/mass spectrometry (GC/MS; HP6890/5973, Hewlett-Packard, USA). The operating conditions and specifications of thermal desorption and GC/MS analysis are described in detail in Text S2. A standard gas mixture of 62 VOCs for USEPA TO-15/17 (1 ppm, Supelco, USA) was used for identification and calibration purposes. In addition, two deuterated compounds (benzene- $\mathrm{d}_{6}$ and ethylbenzene$\mathrm{d}_{10}$, Rigas, Korea) were used as internal standards (IS). A self-manufactured gas spiking apparatus (Fig. S2) was used to prepare standard tube samples and spike the IS to the field samples. Among the 62 VOCs, five highly volatile compounds (propylene, ethanol, Freon 21, chloromethane, and Freon 114) were excluded from the target analytes because they were not efficiently collected by the adsorbent tubes.

The degree of uncertainty for the VOC measurements was evaluated with respect to the analytical precision, method detection limit (MDL), and duplicate precision. Detailed data regarding quality control (QC) and quality assurance (QA) are presented in Table S1. Briefly, the analytical precision of target VOCs ranged from 3.0 to $18.4 \%$. The MDLs for each VOC were evaluated according to the USEPA guidelines (USEPA, 2016a) and estimated to range from 0.02 (benzene) to $0.12 \mathrm{ppb}$ (vinyl chloride). The mean duplicate precision (MDP) values for most VOCs were within the TO17 recommended value of $<30 \%$.
Carbonyls Carbonyls were sampled with the same frequency and duration as VOCs. Samples were collected on 2,4dintrophenylhydrazine (DNPH) cartridges (LpDNPH S10L, Supelco, USA) at a flow rate of $0.8 \mathrm{~L} / \mathrm{min}$ for $3 \mathrm{~h}$ using personal pumps (SKC, USA). Ozone scrubbers were placed in front of the DNPH cartridges to avoid sampling artifacts. Carbonyls were extracted with $3 \mathrm{~mL}$ of acetonitrile, and then analyzed by high-performance liquid chromatography (LC20A HPLC system, Shimadzu, Japan) with a standard mixture of 13 carbonyls (Carbonyl-DNPH Mix 1, Supelco, USA). Details of the carbonyl analytical method are presented in Text S3 and are reported in the literature (Baek et al. 2020a, b; Seo et al. 2014). The analytical precision for all carbonyls tested was $<2.5 \%$. The carbonyl MDLs ranged from 0.02 to $0.03 \mathrm{ppb}$, and the MDP values were all $<30 \%$.

\section{Measurement of particulate HAPs}

Collection of particle samples High-volume samplers (TEPNY1123, Tisch Environmental, USA) were used to collect total suspended particles (TSP). The samplers were operated for $24 \mathrm{~h}$ at a flow rate of $550-600 \mathrm{~L} / \mathrm{min}$. Quartz fiber filters $\left(8^{\prime \prime} \times 10^{\prime \prime}\right.$, QMA filter, Whatman, USA) were used for particle collection and were pretreated at $\sim 400{ }^{\circ} \mathrm{C}$ for $4 \mathrm{~h}$ to remove any organic impurities. The pretreated filters were equilibrated for $24 \mathrm{~h}$ in a desiccator $\left(20 \pm 1{ }^{\circ} \mathrm{C}\right.$ and $\left.45 \pm 5 \%\right)$ and weighed before sampling. Each filter was divided into four pieces of equal size. Two pieces were used for PAH analysis, and the other two were used to determine the TSP and trace elements.

PAHs The protocol for PAH measurement was based on the USEPA TO-13A method. PAHs were extracted from the two filter pieces using a solvent extraction system (Soxtec 2055, Foss, Switzerland) with $80 \mathrm{~mL}$ of an acetone:hexane solution $(1: 9, \mathrm{v} / \mathrm{v})$ for $40 \mathrm{~min}$ at $145^{\circ} \mathrm{C}$, and then rinsed at a rate of 40 50 times/h for $80 \mathrm{~min}$ (Baek et al. 2020a). Before extraction, the filters were spiked with an aliquot of a mixture of five deuterated surrogate standards (SS). The extracted samples were initially concentrated to $\sim 4 \mathrm{~mL}$ using a vacuum evaporator (RapidVap, Labconco, USA) under $\mathrm{N}_{2}$ gas, and then concentrated to $0.5 \mathrm{~mL}$ after being passed through an anhydrous $\mathrm{Na}_{2} \mathrm{SO}_{4}$ cartridge. The concentrated samples were then spiked with a mixture of four internal standards (IS) and analyzed by GC/MS (6890N/5973i, Agilent Technologies, USA) in selected ion monitoring mode. The details of SS, IS, and GC/MS operating conditions are described in Text S4. The standard reference material (SRM) 2260a (Aromatic Hydrocarbons in Toluene, NIST, USA), a mixture of 35 PAHs, was used as the working standard for the qualitative and quantitative analysis of the target analytes. PAH concentrations were determined by the IS method, and each concentration value was corrected by the recovery rate of the corresponding SS. 
The PAH measurements were also evaluated with respect to analytical precision, MDL, and recovery rate, according to the USEPA TO-13A protocol. The detailed QC/QA data for PAHs are presented in Table $\mathrm{S} 2$. The analytical precision for the 35 PAHs ranged from $0.5 \%$ (pyrene) to $25.2 \%$ (coronene). The correlation coefficients for the linearity of the calibration curves (four points) exceeded 0.99. The MDLs for the PAHs ranged from $0.02 \mathrm{ng} / \mathrm{m}^{3}$ for benzo[a]pyrene $(\mathrm{BaP})$ to $0.12 \mathrm{ng} /$ $\mathrm{m}^{3}$ for dibenzo[a,e]pyrene (DaeP). The recovery rates and accuracies of the PAH data were evaluated using the SRM1649b (Urban Dust, NIST, USA). The recovery rates for the 23 PAHs having 3-7 rings ranged from 70.5 to $104.0 \%$ with a mean value of $82.8 \%$. The accuracies were expressed as mean relative errors (MRE) and ranged from 4.0 to $29.6 \%$. Although two-ring PAHs, such as naphthalene and dibenzothiophene, were measured from the particle samples, these data were discarded because of the low recovery rates $(<70 \%)$ and high MRE values $(>30 \%)$.

Trace elements Trace elements were extracted from the piece of each filter sample with a solution of $\mathrm{HCl}(16.75 \%, \mathrm{v} / \mathrm{v})$ and $\mathrm{HNO}_{3}(5.55 \%$, v/v) using a microwave digester (Ethos, Milestone, Italy), according to the USEPA IO-3.1 method. The extracted samples were analyzed using inductively coupled plasma/atomic emission spectrometry (ICP/AES; Optima 3000RL, Perkin Elmer, USA). A total of 16 trace elements ( $\mathrm{Al}, \mathrm{As}, \mathrm{Ca}, \mathrm{Cd}, \mathrm{Co}, \mathrm{Fe}, \mathrm{K}, \mathrm{Mg}, \mathrm{Mn}, \mathrm{Na}, \mathrm{Ni}, \mathrm{Pb}$, $\mathrm{Se}$, Ti, V, and $\mathrm{Zn}$ ) were determined using the ICP multielement standard solution IV (Merck, Germany) and individual standards. Hexavalent chromium (Cr(VI)) was measured only in Incheon during the second year by low-volume sampling according to the method established by the USEPA (2006). Details of the sampling and analytical procedures for $\mathrm{Cr}(\mathrm{VI})$ are presented in Text S4. The QC/QA data for the ICP method are presented in Table $\mathrm{S} 3$. The analytical precision for the trace elements ranged from $2.3 \%(\mathrm{~Pb})$ to $25.4 \%(\mathrm{Se})$. The MDLs ranged from $0.05 \mathrm{ng} / \mathrm{m}^{3}(\mathrm{Cd})$ to $10.93 \mathrm{ng} / \mathrm{m}^{3}(\mathrm{Na})$. The recovery rates of trace elements were examined using SRM1648 (Urban Particulate Matter, NIST, USA). The soilassociated elements, such as $\mathrm{Al}, \mathrm{Ca}, \mathrm{Fe}, \mathrm{K}, \mathrm{Mg}, \mathrm{Na}$, and $\mathrm{Ti}$, had recovery rates that ranged from $45.3 \%$ to $86.1 \%$. However, heavy metals showed good recovery rates, ranging from $80.3 \%(\mathrm{~V})$ to $108.5 \%(\mathrm{~Pb})$; one exception was $\mathrm{Se}$ (25.9\%). The Se data were not included in the risk assessment owing to poor recovery and low detection frequency (DF), both of which were less than $30 \%$.

Organic carbon (OC) and elemental carbon (EC) Atmospheric particulate carbons (OC and EC) were determined from $\mathrm{PM}_{2.5}$ samples, which were collected by low-volume sampling at a flow rate of $16.7 \mathrm{~L} / \mathrm{min}$ for $24 \mathrm{~h}$. A quartz fiber filter $(4.5 \mathrm{~cm}$ dia.) was attached to a filter pack with a cyclone inlet for $\mathrm{PM}_{2.5}$ (URG, USA). The OC and EC were analyzed by the thermal optical transmittance method (OC-EC Aerosol Analyzer, Sunset Lab. Inc., USA), and measured only in Seoul during the first year of the sampling period.

\section{Positive matrix factorization modeling}

PMF is a receptor model that estimates the contribution of each source to the measured concentrations of chemical species based on source compositions, which are also called fingerprints. The goal of using a receptor model is to obtain the chemical mass balance between the measured species concentrations and source profiles. In the PMF model, individual species measured in each sample are expressed as the sum of the contributions from identified sources as follows:

$x_{i j}=\sum_{k=1}^{p} f_{j k} g_{k i}+e_{i j}$

where $x_{i j}$ is the concentration of the $j$ th species (among $m$ species) measured in the $i$ th sample (among $n$ samples); $p$ is the number of independent sources contributing to the samples; $f_{j k}$ is the concentration of the $j$ th species in the $k$ th source profile; $g_{k i}$ is the relative contribution of the $k$ th source to the $i$ th sample; $e_{i j}$ is the error term of the PMF model for the $j$ th species measured on the $i$ th sample. The source profiles and contributions are derived by the PMF model in a manner that minimizes the objective function $\mathrm{Q}$, which is defined as

$Q=\sum_{i=1}^{n} \sum_{j=1}^{m}\left(\frac{e_{i j}}{u_{i j}}\right)^{2}$

where $u_{i j}$ is the uncertainty of the $j$ th species concentration in the $i$ th sample. We used the USEPA PMF 5.0 to identify potential sources of VOCs, PAHs, and HMs. The uncertainty was calculated according to the User Guide of the PMF 5.0 (USEPA 2014), which states the following: If the concentration is less than the MDL of a species, then the uncertainty is replaced by a fixed fraction of the MDL $(5 / 6 \times \mathrm{MDL})$. If the concentration is greater than the MDL, then the uncertainty is calculated as $\left[(\text { error fraction } \times \text { concentration })^{2}+(0.5 \times\right.$ $\left.\mathrm{MDL})^{2}\right]^{1 / 2}$. According to $\mathrm{Wu}$ et al. (2009), the mean sourcespecific concentrations $\left(x_{j k}^{*}\right)$ of individual HAPs can be calculated as follows:

$x_{j k}^{*}=f_{j k} \times g_{k}^{*}$

where $x_{j k}^{*}$ is the mean concentration of the $j$ th species from the $k$ th source, $f_{j k}$, which is also used in Eq. (1); $g_{k}^{*}$ is the mean contribution from the $k$ th source. In this study, the calculated $x_{j k}^{*}$ values were used to estimate the health risk caused by an identified source. 


\section{Toxicity information and health risk assessment}

In this study, potential health risks were evaluated only for chronic exposure to air toxics via inhalation. To assess these risks, we applied a point estimation approach for a screening-level health risk assessment that has been adopted in several studies (Bari and Kindzierski 2017, 2018; Fox et al. 2004; Jia and Foran 2013; Xiong et al. 2020; Wu et al. 2009, 2011). The toxicity values applied in this study are presented in Tables S4-S6. The cancer risk (CR) for a specific HAP was calculated by its mean concentration $\left(x_{i j}^{*}\right)$ and the corresponding inhalation unit risk (UR) factor, and the non-cancer risk was estimated by the hazard quotient (HQ) as follows:

$$
C R_{j}=x_{i j}^{*} \times U R_{j}
$$

$H Q_{j}=x_{i j}^{*} / R f C_{j}$

where $C R_{j}, H Q_{j}, U R_{j}$, and $R f C_{j}$ are the mean cancer risk, mean non-cancer risk, unit risk, and reference concentration (RfC) for the $j$ th species, respectively. The UR values were obtained from the USEPA (2018a, b, c), the California EPA (Cal EPA 2018), and the World Health Organization (WHO 2000). The RfC values were also obtained from the USEPA (USEPA 1997, 2018b). When no RfC was available in the USEPA database, we used the reference exposure levels (REL) provided by the California EPA (Cal EPA 2018) or minimal risk levels (MRL) reported by the US Agency for Toxic Substances and Disease Registry (ATSDR 2016) as a substitute for the RfC. If two or more toxicity values differed for any species, the more conservative value was taken. HAPs for which no UR, RfC, REL, or MRL value was available were not included in the risk calculation. Risk apportionment of identified sources was determined by calculating source-specific cancer and non-cancer risks as follows:

$$
\begin{aligned}
& C R_{k}=\sum_{j=1}^{m} x_{j k}^{*} \times U R_{j} \\
& H Q_{k}=\sum_{j=1}^{m} \frac{x_{j k}^{*}}{R f C_{j}}
\end{aligned}
$$

where $C R_{k}$ and $H Q_{k}$ are the cancer and non-cancer risks, respectively, posed by the $k$ th source, and $x_{j k}^{*}$ is defined in Eq. (3). For PMF modeling and risk assessment, the unit of measurement for VOCs was converted from $\mathrm{ppb}$ to $\mu \mathrm{g} / \mathrm{m}^{3}$ (at $20{ }^{\circ} \mathrm{C}, 1 \mathrm{~atm}$ ).

\section{Results and discussion}

\section{Spatial distributions of HAP concentrations}

The measured concentrations of selected HAPs (DF $>30 \%$ ) in Seoul and Incheon are summarized in Table 2, and detailed data for each site in the two cities are presented in Tables S7 (Seoul) and S8 (Incheon). In this study, the selection criteria were based on three factors: abundance (concentration), ubiquity (DF), and toxicity (carcinogenic or non-carcinogenic impact). Benzene, formaldehyde (FALD), and $\mathrm{BaP}$, which are well-known carcinogens (USEPA 2018a; IARC 2018), were detected in all samples in both cities. The most abundant VOC and PAH compounds were toluene (citywide average: $4.79 \mathrm{ppb}$ in Seoul and $4.88 \mathrm{ppb}$ in Incheon) and fluoranthene (FLRTH; $1.59 \mathrm{ng} / \mathrm{m}^{3}$ in Seoul and $2.59 \mathrm{ng} / \mathrm{m}^{3}$ in Incheon), respectively. Within the categories of VOCs, PAHs, and HMs, the distribution of the HAPs detected was broad and variable; the variability in the HAP concentrations reflected the variability in the sources and atmospheric behavior of each species. However, the variability across the sampling sites in each city was relatively small (Tables S7 and S8). Analysis of variance (ANOVA) indicated that, among the 60 species, a statistically significant difference $(p<0.05)$ in mean concentrations between different sampling sites was observed for 10 and 17 species in Seoul and Incheon, respectively. Two reasons for the lower variability are that all sampling sites were located in non-industrial areas and that the sampling sites in each city were affected by the same airshed.

Overall, the mean concentrations of HAPs were higher in Incheon than in Seoul. Because HAPs were measured in Seoul and Incheon at different times, a direct comparison between the two cities may not be appropriate owing to the lack of concurrency. Therefore, we evaluated air quality by focusing on the levels of criteria pollutants $\left(\mathrm{SO}_{2}, \mathrm{NO}_{2}, \mathrm{CO}\right.$, and $\left.\mathrm{PM}_{10}\right)$ and determining whether significant changes in air quality occurred from 2013 to 2015. The criteria pollutant data were available from Air Korea (2020). The monthly variations in the ambient levels of the four criteria pollutants are presented in Fig. S2, and $t$ test revealed that there were no significant changes $(p>0.05)$ between the first and second year during the sampling periods of this study. The only exceptions were the $\mathrm{PM}_{10}$ levels in February and March, 2015, when Asian dust events occurred. Therefore, we compared the HAP levels between the two cities by assuming that the overall air quality in each city from 2013 to 2015 was equal. A comparison of the cumulative probability distributions of the data for the major HAPs between the two cities is shown in Fig. 2. Among VOCs, the concentration of trichloroethylene (TCE) was higher in Incheon than Seoul $(p<0.05)$, but that of methyl tert-butyl ether (MTBE) was higher in Seoul. Levels of other VOCs, such as benzene, toluene, xylenes, and FALD, were similar between the two cities $(p>0.05)$. TCE is a chlorinated 
Table 2 Concentrations of HAPs (VOCs in ppb, PAHs, and HMs in $\mathrm{ng} / \mathrm{m}^{3}$ ) in Seoul and Incheon

\begin{tabular}{|c|c|c|c|c|c|c|c|c|c|}
\hline \multirow[t]{2}{*}{ HAP } & \multirow{2}{*}{$\begin{array}{l}\text { Abbre- } \\
\text { viation }\end{array}$} & \multicolumn{4}{|l|}{ Seoul } & \multicolumn{4}{|c|}{ Incheon } \\
\hline & & Mean & $\mathrm{SD}^{\mathrm{a})}$ & $\operatorname{Max}^{\mathrm{b})}$ & $\mathrm{DF}^{\mathrm{c}}(\%)$ & Mean & SD & $\operatorname{Max}$ & $\mathrm{DF}(\%)$ \\
\hline Iso-propyl alcohol & IPA & 0.41 & 0.85 & 6.27 & 92.2 & 0.46 & 0.94 & 5.34 & 78.9 \\
\hline Methyl tert-butyl ether & MTBE & 0.39 & 0.35 & 2.16 & 98.3 & 0.24 & 0.21 & 1.62 & 98.2 \\
\hline Vinyl acetate & VACT & 0.33 & 0.25 & 1.91 & 90.0 & 0.41 & 0.37 & 2.53 & 99.5 \\
\hline Ethyl acetate & EACT & 1.55 & 2.18 & 11.75 & 95.6 & 3.49 & 5.78 & 40.78 & 98.2 \\
\hline Hexane & - & 0.63 & 0.63 & 4.80 & 99.4 & 0.56 & 0.61 & 5.76 & 99.1 \\
\hline Chloroform & CLFM & 0.02 & 0.02 & 0.09 & 71.1 & 0.03 & 0.06 & 0.49 & 61.0 \\
\hline 1,2-Dichloroethane & 12DCE & 0.01 & 0.02 & 0.13 & 46.7 & 0.03 & 0.04 & 0.17 & 47.7 \\
\hline Benzene & - & 0.48 & 0.28 & 1.69 & 100.0 & 0.61 & 0.42 & 2.59 & 100.0 \\
\hline Carbon tetrachloride & CTTC & 0.09 & 0.03 & 0.21 & 100.0 & 0.09 & 0.03 & 0.20 & 99.1 \\
\hline Cyclohexane & $\mathrm{CHXN}$ & 0.18 & 0.17 & 0.99 & 98.9 & 0.17 & 0.17 & 1.23 & 87.6 \\
\hline 1,2-Dichloropropane & $12 \mathrm{DCP}$ & 0.03 & 0.04 & 0.25 & 45.0 & 0.05 & 0.08 & 0.57 & 47.7 \\
\hline Trichloroethylene & TCE & 0.18 & 0.26 & 2.02 & 81.7 & 0.46 & 0.73 & 4.79 & 78.4 \\
\hline Heptane & - & 0.15 & 0.12 & 0.68 & 99.4 & 0.16 & 0.16 & 1.25 & 90.8 \\
\hline Methyl isobutyl ketone & MIBK & 0.16 & 0.18 & 1.25 & 93.3 & 0.30 & 0.55 & 4.47 & 84.4 \\
\hline Toluene & - & 4.79 & 4.06 & 23.69 & 100.0 & 4.88 & 6.73 & 40.92 & 100.0 \\
\hline Tetrachloroethylene & TTCE & 0.07 & 0.31 & 4.11 & 77.2 & 0.02 & 0.05 & 0.48 & 49.5 \\
\hline Ethylbenzene & EBZN & 0.75 & 0.72 & 3.24 & 99.4 & 0.62 & 0.67 & 5.83 & 100.0 \\
\hline$m, p$-Xylenes & $m p X Y L$ & 0.84 & 0.83 & 6.42 & 98.9 & 0.89 & 1.06 & 8.81 & 100.0 \\
\hline Styrene & - & 0.09 & 0.35 & 0.81 & 93.9 & 0.08 & 0.11 & 0.99 & 93.6 \\
\hline$o$-Xylene & oXYL & 0.31 & 0.31 & 2.43 & 99.4 & 0.32 & 0.35 & 2.72 & 99.5 \\
\hline 1,3,5-Trimethylbenzene & $135 \mathrm{TMB}$ & 0.03 & 0.02 & 0.16 & 92.2 & 0.04 & 0.03 & 0.24 & 87.2 \\
\hline 1,2,4-Trimethylbenzene & $124 \mathrm{TMB}$ & 0.11 & 0.10 & 0.70 & 98.9 & 0.12 & 0.11 & 0.90 & 98.6 \\
\hline Formaldehyde & FALD & 2.96 & 1.91 & 8.57 & 100.0 & 2.94 & 1.61 & 10.54 & 100.0 \\
\hline Acetaldehyde & AALD & 2.01 & 0.73 & 4.08 & 100.0 & 1.98 & 0.77 & 4.76 & 100.0 \\
\hline Acetone & - & 4.67 & 2.90 & 15.20 & 100.0 & 3.33 & 1.56 & 11.10 & 100.0 \\
\hline Propionaldehyde & PALD & 0.20 & 0.10 & 0.55 & 99.4 & 0.20 & 0.11 & 0.63 & 100.0 \\
\hline Methyl ethyl ketone & MEK & 0.70 & 0.52 & 2.90 & 99.4 & 0.61 & 0.44 & 2.83 & 99.5 \\
\hline Phenanthrene & PHEN & 1.47 & 1.27 & 6.97 & 100.0 & 1.71 & 1.98 & 6.94 & 100.0 \\
\hline Anthracene & ANTHR & 0.11 & 0.07 & 0.38 & 100.0 & 0.10 & 0.12 & 0.57 & 69.6 \\
\hline 4H-Cyclopenta[d,e,f]phenanthrene & CdefPh & 0.16 & 0.14 & 0.72 & 87.8 & 0.22 & 0.26 & 1.05 & 69.6 \\
\hline Fluoranthene & FLRTH & 1.59 & 1.32 & 6.55 & 100.0 & 2.59 & 3.04 & 11.41 & 100.0 \\
\hline Pyrene & - & 1.31 & 1.02 & 4.79 & 100.0 & 2.05 & 2.40 & 10.06 & 100.0 \\
\hline Benzo $[\mathrm{c}]$ phenanthrene & $\mathrm{BcPh}$ & 0.16 & 0.12 & 0.54 & 96.7 & 0.26 & 0.34 & 1.45 & 81.3 \\
\hline $\begin{array}{l}\text { Benzo[g,h,i]fluoranthene } \\
+ \text { Cyclopenta[c,d]pyrene }\end{array}$ & BghiF+CcdP & 0.62 & 0.44 & 1.88 & 100.0 & 1.04 & 1.30 & 5.54 & 100.0 \\
\hline Benz[a]anthracene & $\mathrm{BaA}$ & 0.44 & 0.34 & 1.34 & 100.0 & 0.77 & 0.96 & 4.25 & 98.2 \\
\hline Triphenylene & TRPNL & 0.20 & 0.13 & 0.55 & 98.9 & 0.39 & 0.42 & 1.69 & 99.1 \\
\hline Chrysene & - & 0.83 & 0.58 & 2.51 & 100.0 & 1.39 & 1.55 & 6.06 & 100.0 \\
\hline $\begin{array}{l}\text { Benzo[b]fluoranthene } \\
+ \text { Benzo[j]fluoranthene }\end{array}$ & $\mathrm{BbF}+\mathrm{BjF}$ & 1.26 & 0.76 & 3.46 & 100.0 & 1.98 & 1.88 & 7.22 & 100.0 \\
\hline Benzo[k]fluoranthene & $\mathrm{BkF}$ & 0.34 & 0.21 & 0.92 & 100.0 & 0.50 & 0.50 & 1.92 & 100.0 \\
\hline Benzo[a]fluoranthene & $\mathrm{BaF}$ & 0.18 & 0.14 & 0.62 & 98.9 & 0.21 & 0.24 & 1.13 & 83.0 \\
\hline Benzo[e]pyrene & $\mathrm{BeP}$ & 0.55 & 0.33 & 1.52 & 100.0 & 0.83 & 0.78 & 3.05 & 100.0 \\
\hline Benzo[a]pyrene & $\mathrm{BaP}$ & 0.57 & 0.39 & 1.76 & 100.0 & 0.82 & 0.83 & 3.72 & 100.0 \\
\hline Perylene & - & 0.09 & 0.07 & 0.31 & 92.2 & 0.13 & 0.14 & 0.64 & 76.8 \\
\hline Dibenz[a,j]anthracene & DajA & 0.09 & 0.06 & 0.27 & 65.6 & 0.10 & 0.08 & 0.33 & 70.5 \\
\hline Indeno $[1,2,3-c, d]$ pyrene & I123P & 0.49 & 0.29 & 1.38 & 100.0 & 0.62 & 0.59 & 2.61 & 100.0 \\
\hline Dibenz $[\mathrm{a}, \mathrm{h}]$ anthracene & DahA+DacA & 0.14 & 0.08 & 0.36 & 100.0 & 0.18 & 0.14 & 0.58 & 100.0 \\
\hline
\end{tabular}


Table 2 (continued)

\begin{tabular}{|c|c|c|c|c|c|c|c|c|c|}
\hline \multirow[t]{2}{*}{ HAP } & \multirow{2}{*}{$\begin{array}{l}\text { Abbre- } \\
\text { viation }\end{array}$} & \multicolumn{4}{|l|}{ Seoul } & \multicolumn{4}{|c|}{ Incheon } \\
\hline & & Mean & $\mathrm{SD}^{\mathrm{a})}$ & $\operatorname{Max}^{\mathrm{b})}$ & $\mathrm{DF}^{\mathrm{c})}(\%)$ & Mean & SD & $\operatorname{Max}$ & $\mathrm{DF}(\%)$ \\
\hline \multicolumn{10}{|l|}{ + Dibenz[a,c]anthracene } \\
\hline Picene & - & 0.12 & 0.08 & 0.47 & 77.8 & 0.13 & 0.12 & 0.50 & 77.7 \\
\hline Benzo[g,h,i]perylene & BghiP & 0.71 & 0.39 & 2.01 & 100.0 & 0.87 & 0.81 & 3.59 & 100.0 \\
\hline Anthanthrene & ANTHN & 0.18 & 0.13 & 0.60 & 83.3 & 0.18 & 0.23 & 1.11 & 73.2 \\
\hline Dibenzo[b,k]fluoranthene & DbkF & 0.21 & 0.14 & 0.68 & 80.0 & 0.21 & 0.23 & 1.04 & 75.9 \\
\hline Coronene & - & 0.37 & 0.18 & 1.13 & 100.0 & 0.31 & 0.30 & 1.59 & 94.6 \\
\hline Arsenic & As & 4.09 & 3.54 & 15.64 & 84.7 & 6.88 & 6.20 & 33.22 & 99.1 \\
\hline Cadmium & $\mathrm{Cd}$ & 1.21 & 1.86 & 12.15 & 92.9 & 1.34 & 1.31 & 6.53 & 84.8 \\
\hline Cobalt & Co & 0.75 & 0.38 & 1.85 & 98.8 & 1.05 & 1.17 & 4.69 & 78.6 \\
\hline Hexavalent chromium & $\mathrm{Cr}(\mathrm{VI})$ & - & - & - & - & 0.10 & 0.10 & 0.57 & 69.6 \\
\hline Manganese & $\mathrm{Mn}$ & 41.13 & 22.33 & 109.11 & 100.0 & 76.16 & 65.37 & 277.17 & 100.0 \\
\hline Nickel & $\mathrm{Ni}$ & 5.40 & 5.11 & 31.22 & 100.0 & 10.16 & 8.39 & 35.52 & 91.1 \\
\hline Lead & $\mathrm{Pb}$ & 34.04 & 24.07 & 142.42 & 100.0 & 57.23 & 47.50 & 357.28 & 98.2 \\
\hline Vanadium & $\mathrm{V}$ & 4.23 & 2.81 & 14.32 & 100.0 & 12.24 & 15.51 & 77.32 & 99.1 \\
\hline $\mathrm{TSP}\left(\mu \mathrm{g} / \mathrm{m}^{3}\right)$ & - & 87.6 & 30.8 & 178.1 & 100.0 & 117.3 & 75.6 & 375.2 & 100.0 \\
\hline
\end{tabular}

a) SD standard deviation; b) MAX: maximum; c) DF: detection frequency

organic solvent widely used for the vapor degreasing of metal parts (USEPA 2016b). MTBE is a good indicator of vehicle exhaust because it is used in gasoline as an anti-knocking agent (Hsieh et al. 2006). The levels of PAHs and HMs were higher in Incheon than in Seoul. The results suggest that the Incheon area is more affected by industrial activities than Seoul, despite its smaller population.

The concentration ratios of some specific PAHs have been widely used to characterize and identify potential emission sources of PAHs (Ravindra et al. 2008; Tobiszewski and Namieśnik 2012; Yunker et al. 2002). Typical PAHs used in the diagnostic ratios to differentiate pyrogenic combustion from petrogenic sources are FLRTH and pyrene, benzo[A]anthracene (BaA) and chrysene, and indeo[1,2,3-c,d]pyrene (I123P) and benzo[g,h,i]perylene (BghiP). Spatiotemporal distributions of the diagnostic ratios for FLRTH/(FLRTH+pyrene), BaA/ (BaA+chrysene), and I123P/(I123P+BghiP) from this study are summarized in Table S9, while cross plots of FLRTH/(FLRTH+ pyrene) and I123P/(I123P+BghiP) are presented in Fig. S3. According to the diagnostic ratios data, it can be seen that petroleum fuel combustion, traffic-related emission, and biomass/coal combustion are the main affecting factors contributing to the atmospheric PAH concentrations in the Soul-Incheon area. However, the diagnostic ratio method is still very uncertain and has many difficulties in distinguishing similar sources (Ravindra et al. 2008; Tobiszewski and Namieśnik 2012). Therefore, it seems to be the best to use the method as a screening tool for approximate identification of $\mathrm{PAH}$ sources.

\section{Relationship between HAP concentrations and ambient temperature}

Some HAPs are correlated with industrial activities, and others are correlated with fossil fuel combustion (Baek et al. 2019; Kim et al. 2020). Accordingly, the seasonal variability of HAPs may be different for individual species. In general, industrial activities are expected to be constant throughout the year, but the use of fossil fuels will vary depending on the ambient temperature. Therefore, instead of four seasons, we divided the data into two groups for each city: heating (from November through March) and non-heating periods (from April through October), based on the annual average temperature of $14.5^{\circ} \mathrm{C}$ in the SIMA. The average concentrations of selected HAPs measured during the heating and non-heating periods in Seoul and Incheon are shown in Fig. 3. Three distinct patterns were observed: (i) VOCs (except benzene and carbonyls) exhibited no statistically significant differences between the two periods; (ii) combustion-related HAPs, such as benzene, PAHs, As, and Cd, exhibited higher levels during the heating period than during the non-heating period; and (iii) carbonyl concentrations increased during the non-heating period; this increase was partially due to photochemical reactions in the atmosphere that occur during summer (Kim et al. 2020; Scheffe et al. 2016).

Seasonal variations in PAH concentrations occur in temperate zones, depending on the magnitude of fossil fuel combustion (Dat and Chang 2017; Li et al. 2009; Thang et al. 

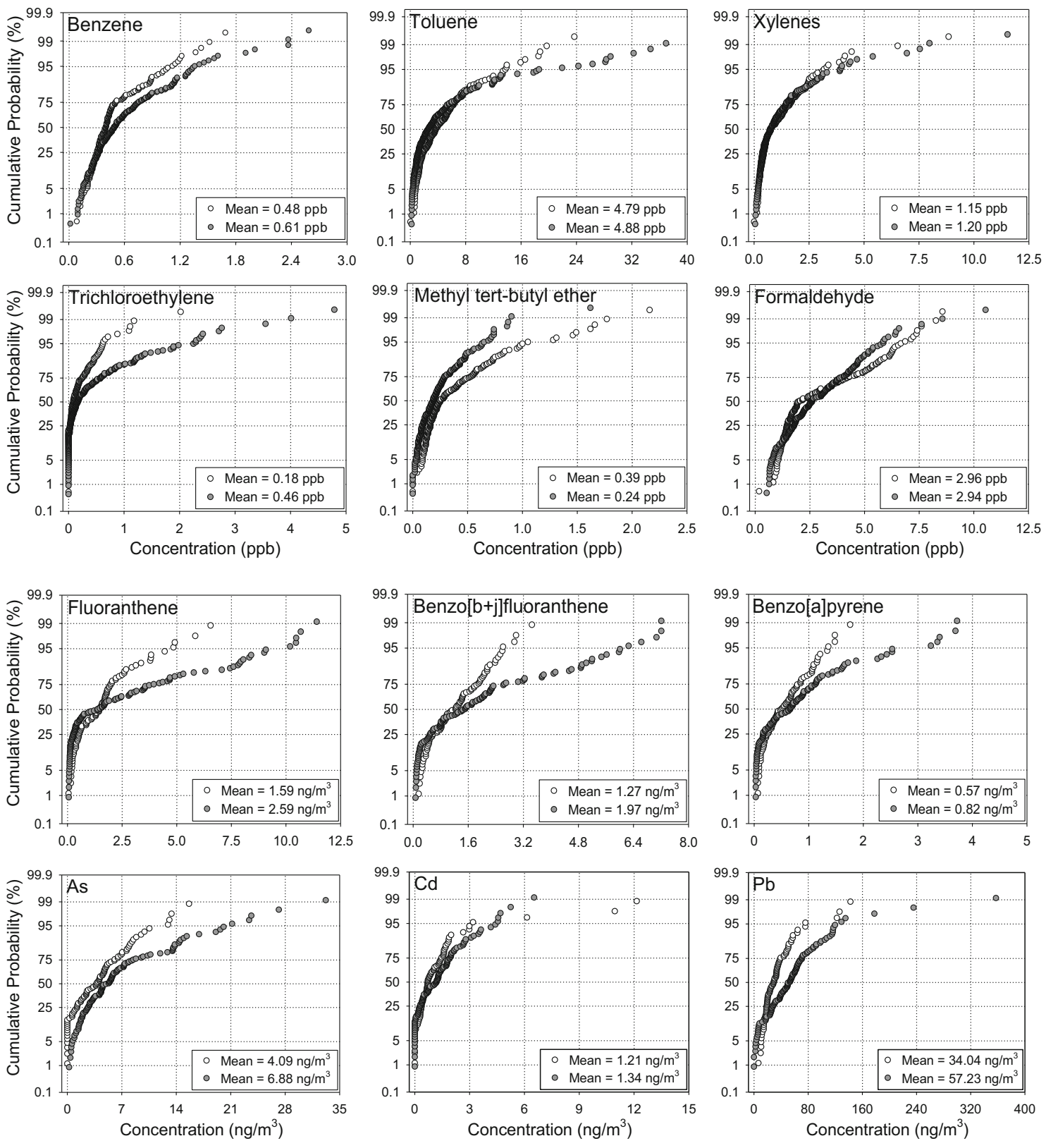

○ Seoul - Incheon

Fig. 2 Cumulative probability distributions of selected HAP concentrations in Seoul and Incheon

2019). PAH levels in the SIMA were typically 3-10 times higher during cold seasons than during warm seasons. The increased levels of PAHs in winter occurred for several reasons: increased fossil fuel consumption, enhanced vapor-toparticle transformation, and cold-start emissions from automobiles (Cheruiyot et al. 2015; Dat and Chang 2017; Ravindra et al. 2008). In addition, transboundary pollution from China and North Korea, can contribute to PAH levels (Kim et al. 2013; Lee et al. 2006; Thang et al. 2019). Coal is widely used for space-heating in the northern parts of China and North Korea from October to March (Kim et al. 2013; Lee et al. 2006, 2011), which increases PAH emissions. Therefore, the PAH levels in the SIMA are affected not only by local sources but also by PAH emissions in China and North Korea from prevailing winds. Similar trends have been reported in Seoul (Kim et al. 2013; Lee et al. 2011) and on the west coast of Korea (Baek et al. 2020a; Lee et al. 2006; Thang et al. 2019). To validate our hypothesis about transboundary transport of PAHs during cold seasons, we conducted hybrid single-particle Lagrangian integrated trajectory (HYSPLIT) modeling (HYSPLIT, 2019) for February 5 and 7 as days when the maximum $\left(35.44 \mathrm{ng} / \mathrm{m}^{3}\right)$ and minimum $(5.54 \mathrm{ng} /$ $\mathrm{m}^{3}$ ) concentrations of $\Sigma 35 \mathrm{PAHs}$, respectively, were measured during the winter campaign in Seoul (Fig. S4). The back 

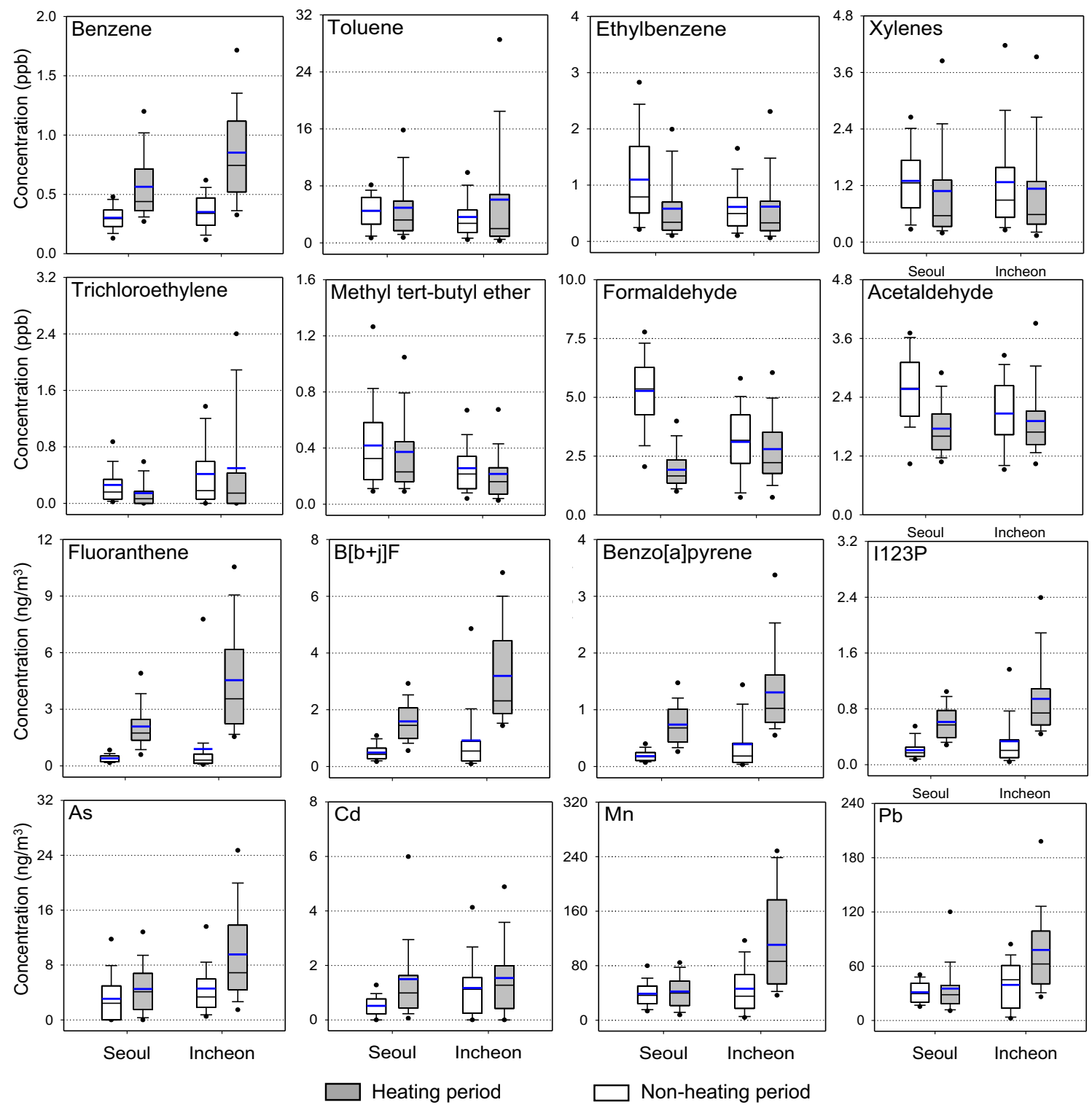

Fig. 3 Concentrations of selected HAPs in Seoul and Incheon during heating and non-heating periods

trajectories of air parcels that arrived in Seoul on February 5 were through China and North Korea, whereas those on February 7 were through the East Sea from Siberia.

Unexpectedly high levels of Mn were observed during the heating period in Incheon (Fig. 3). Asian dust was observed in the SIMA for five days peaking on March 21, 2015. In March 18, just before the Asian dust invasion, the average level of TSP in Incheon was $102.4 \mu \mathrm{g} / \mathrm{m}^{3}$, but it increased 3.7 times (reaching $375.2 \mu \mathrm{g} / \mathrm{m}^{3}$ ) and then returned to 106.5 $\mu \mathrm{g} / \mathrm{m}^{3}$ on March 24. During the same period, Mn levels increased from 54.1 to $233.0 \mathrm{ng} / \mathrm{m}^{3}$ and then decreased to 63.6 $\mathrm{ng} / \mathrm{m}^{3}$ after the Asian dust event. The iron-steel industry is a major source of Mn emissions (Baek et al. 2020a), but Mn is also in the soil (Chow 1995), which is the primary component of Asian dust. Therefore, the levels of Mn during the heating period in Incheon are attributed to Asian dust. This conclusion was also validated by HYSPLIT modeling for March 18 and 21 (Fig. S5). The back trajectories show that air parcels arrived at Incheon through the East Sea on March 18, whereas they reached Incheon through the Yellow Sea from China on March 21. During the same period, there were no significant changes in the levels of PAHs and VOCs.

\section{Assessment of health risks from HAP exposures}

The data measured at each site were pooled for each city to assess the health impacts of HAPs on the residents of Seoul and Incheon. The cancer risk for an individual species was calculated using the citywide average and its corresponding UR. The UR is defined as the excess lifetime risk of a chronic exposure to $1 \mu \mathrm{g} / \mathrm{m}^{3}$ of a pollutant (WHO 2000). The USEPA suggested $1 \times 10^{-6}$ and $1 \times 10^{-4}$ as acceptable and tolerable 
cancer risk levels, respectively (USEPA 2009). The mean concentrations and point estimates of excess cancer risk due to inhalation exposure to HAPs in Seoul and Incheon are presented in Table 3, in descending order of risk. UR data were available for 49 species (see Tables S4 and S6 for details), and descriptive statistics are given for the top 25 HAPs after excluding rarely detected (DF $<30 \%)$ or lowrisk species. For the risk calculation, concentrations of coeluted PAHs were divided equally.

The cancer risks associated with individual HAPs were generally higher in Incheon than in Seoul. BaP had the highest cancer risk in both cities, followed by FALD, As, and benzene. The number of HAPs whose cancer risk exceeded $1 \times$ $10^{-6}$ (acceptable) in Seoul and Incheon were 22 and 24, respectively. The cumulative cancer risks $(\Sigma C R)$ were $2.0 \times$ $10^{-4}$ (Seoul) and $2.7 \times 10^{-4}$ (Incheon). In Seoul, VOCs, PAHs, and HMs contributed $43.8 \%, 42.0 \%$, and $14.2 \%$, respectively to the $\Sigma \mathrm{CR}$, and in Incheon, the contributions were $37.1 \%, 46.0 \%$, and $16.9 \%$. The difference in the contributions of HAP subgroups to the $\Sigma$ CR between Seoul and Incheon indicated that the emission sources of HAPs in the SIMA were predominantly associated with fossil fuel combustion and industrial activities.

Any direct comparison of $\Sigma \mathrm{CR}$ between this and other studies needs to be done cautiously because estimated risks depend on the number of HAP species included in the risk assessment. In addition, the cancer risk of PAHs can vary greatly depending on which UR value is used. In this study, the $\mathrm{WHO}$ value for $\mathrm{BaP}\left(8.7 \times 10^{-2}\right)$ was applied, but it is almost 100 times greater than the USEPA UR value $(6.0 \mathrm{x}$ $\left.10^{-4}\right)$. Recently, Baek et al. $(2020 \mathrm{a}, \mathrm{b})$ reported cancer risk assessment for a wide range of HAPs in major industrial cities in Korea, such as Pohang and Ulsan. Their results are comparable to those reported in this study in terms of the number of target HAPs, sampling sites, and collected samples. The $\Sigma \mathrm{CR}$ levels in Seoul and Incheon were approximately equal to that of the residential areas $\left(2.3 \times 10^{-4}\right.$ for 28 HAPs $)$ of Pohang, a steel industrial city. However, the $\Sigma \mathrm{CR}$ levels were higher than that of the residential areas $\left(1.7 \times 10^{-4}\right.$ for 35 HAPs $)$ in Ulsan, a heavily industrialized city with petrochemical, shipbuilding, and automotive industries. It is somewhat surprising that HAP risk in the SIMA was greater than or equal to those in residential areas of industrial cities that have been cited for severe air pollution since the 1990s.

The non-cancer risk for a specific HAP was expressed as an HQ, according to Eq. (5). The HQ is the ratio of the potential exposure level to a substance and the level at which no adverse effects are expected (USEPA 2020). Non-carcinogenic reference values (RfC, REL, or MRL) were available for 63 species (Tables S4 and S6). Only 35 species (DF $\geq 30 \%)$ were included in the non-cancer risk calculation, and the HQs for the top 25 species are presented in Table S10. TCE showed the highest HQ for both cities. However, the overall non- cancer risk was less than the overall cancer risk because the only species with an HQ > 1 was TCE in Incheon. The cumulative HQ ( $\Sigma \mathrm{HQ}$ ) values for the top $25 \mathrm{HAPs}$ were 2.84 and 4.45 in Seoul and Incheon, respectively. The $\Sigma H Q$ values in this study were comparable to those in the residential areas of industrial cities, such as Pohang (3.4) and Ulsan (2.4), but much lower than the industrial area (10.0) of Ulsan (Baek et al. 2020a, b). VOC, HM, and PAH contributions to the $\Sigma$ HQ were $59.1 \%, 30.7 \%$, and $10.2 \%$, respectively, in Seoul and $58.0 \%, 32.8 \%$, and $9.2 \%$ in Incheon. However, the question of whether all HAPs impact the same organ or organ system remains unanswered. Little is known about the interactions among pollutants and the health risks posed by longterm exposure to HAPs. Nevertheless, the high $\Sigma \mathrm{HQ}$ values imply that the SIMA residents have experienced concurrent HAP exposures that may pose non-cancer risks for various endpoints.

There are uncertainties associated with the deterministic screening approach used in this study. For HAPs with known toxicity, most of the uncertainty is related to the assumptions applied to the quantitative derivations of toxicity values, such as UR, RfC, REL, and MRL (Bari and Kindzierski 2018). This study may underestimate or overestimate the health risks. Some hazardous species were not measured in this study (e.g., highly volatile hydrocarbons and vapor-phase PAHs), and some measured species were excluded from the risk assessment due to the lack of toxicity data. Overestimation could occur because (i) more conservative values were applied to some calculations, (ii) mean values from one year measurements were used to calculate long-term (70-year lifespan) toxicity values, and (iii) $50 \%$ of the MDL value was substituted when measured values were less than the MDL. Many of these limitations have also been addressed in previous studies (Bari and Kindzierski 2017, 2018; Jia and Foran 2013; Ramírez et al. 2012; Wu et al. 2009, 2011). In addition, there was a possibility of overestimation of health risks because we determined PAHs and HMs from TSP samples, which would be theoretically higher levels than those from inhalable $\mathrm{PM}$ samples (such as $\mathrm{PM}_{10}$ or $\mathrm{PM}_{2.5}$ ) (Cheruiyot et al. 2015; Chow 1995).

\section{Source apportionment of HAP concentrations}

We applied PMF to the VOC, PAH, and HM datasets from Seoul and Incheon to provide quantitative information about the contributions of each source to the measured concentration of a specific HAP. In this study, the factors identified for each dataset were evaluated for interpretability, plausibility, and the diagnostic results of error estimation. Each task of the PMF was conducted by trial and error, and the final solution was optimized by considering $\mathrm{Q}_{\text {roust }} / \mathrm{Q}_{\text {true }}, \mathrm{Q}_{\text {true }} / \mathrm{Q}_{\text {exp }}$, the displacement (DISP) of factor elements, and bootstrap (BS) mapping, as suggested in the PMF 5.0 guidelines. BS-DISP error 
Table 3 Source contributions to the concentrations of selected VOCs $\left(\mu \mathrm{g} / \mathrm{m}^{3}\right)$, PAHs $\left(\mathrm{ng} / \mathrm{m}^{3}\right)$, and HMs $\left(\mathrm{ng} / \mathrm{m}^{3}\right)$ in Seoul and Incheon, estimated by PMF modeling

\begin{tabular}{|c|c|c|c|c|c|c|c|c|c|c|}
\hline \multirow[t]{9}{*}{ Task I } & Seoul VOC Source & IPA & MTBE & Benzene & TCE & Toluene & EBZN & XYLs & FALD & AALD \\
\hline & Vehicle exhaust & 0.02 & 0.89 & 0.19 & $<0.01$ & 2.42 & 0.62 & 1.01 & 0.63 & 0.63 \\
\hline & Petroleum solvent & $<0.01$ & 0.02 & 0.06 & $<0.01$ & 4.98 & 1.75 & 2.88 & 0.12 & $<0.01$ \\
\hline & Fuel combustion & 0.04 & 0.13 & 0.63 & 0.06 & 3.38 & $<0.01$ & 0.06 & $<0.01$ & 0.77 \\
\hline & Carbonyl compounds & 0.01 & 0.08 & 0.23 & 0.18 & $<0.01$ & 0.20 & 0.23 & 2.46 & 2.11 \\
\hline & Industrial emission (I) & 0.79 & 0.02 & 0.28 & 0.01 & 1.21 & 0.00 & 0.12 & 0.03 & 0.23 \\
\hline & Industrial emission (II) & 0.07 & 0.15 & 0.06 & 0.69 & 4.57 & 0.47 & 0.71 & 0.37 & 0.00 \\
\hline & Total estimated & 0.93 & 1.29 & 1.45 & 0.94 & 16.56 & 3.04 & 5.01 & 3.61 & 3.74 \\
\hline & Total measured & 1.03 & 1.42 & 1.55 & 1.00 & 18.36 & 3.33 & 5.10 & 3.70 & 3.68 \\
\hline \multirow[t]{9}{*}{ Task II } & Incheon VOC Source & IPA & MTBE & Benzene & TCE & Toluene & EBZN & XYLs & FALD & AALD \\
\hline & Vehicle exhaust & $<0.01$ & 0.50 & 0.13 & $<0.01$ & 0.79 & 0.09 & 0.16 & 0.00 & 0.23 \\
\hline & Petroleum solvent & $<0.01$ & $<0.01$ & 0.04 & $<0.01$ & 2.14 & 1.21 & 2.65 & 0.67 & 0.41 \\
\hline & Fuel combustion & 0.40 & $<0.01$ & 1.46 & 0.08 & 0.34 & 0.04 & 0.12 & $<0.01$ & 0.35 \\
\hline & Carbonyl compounds & 0.04 & 0.18 & 0.18 & 0.28 & 1.19 & 0.21 & 0.39 & 2.48 & 2.50 \\
\hline & Industrial emission (I) & 0.46 & 0.01 & 0.00 & 0.15 & 7.86 & 0.19 & 0.15 & 0.02 & 0.00 \\
\hline & Industrial emission (II) & 0.00 & 0.14 & 0.21 & 1.82 & 4.53 & 0.84 & 1.60 & 0.13 & 0.03 \\
\hline & Total estimated & 0.90 & 0.83 & 2.03 & 2.33 & 16.85 & 2.59 & 5.07 & 3.30 & 3.53 \\
\hline & Total measured & 1.16 & 0.86 & 1.98 & 2.50 & 18.72 & 2.72 & 5.30 & 3.67 & 3.63 \\
\hline \multirow[t]{8}{*}{ Task III } & Seoul PAH source & PHEN & FLRTH & $\mathrm{BaA}$ & $\begin{array}{r}\mathrm{B}[\mathrm{b}+ \\
\mathrm{j}] \mathrm{F}\end{array}$ & $\mathrm{BkF}$ & $\mathrm{BaP}$ & $\mathrm{I} 123 \mathrm{P}$ & BghiP & ANTHN \\
\hline & Coal combustion & 0.12 & 1.12 & $<0.01$ & 0.40 & 0.11 & 0.15 & 0.14 & 0.13 & 0.04 \\
\hline & Oil combustion & 1.04 & 0.34 & $<0.01$ & 0.07 & 0.02 & 0.03 & 0.04 & 0.04 & 0.02 \\
\hline & Diesel vehicle & $<0.01$ & 0.06 & 0.09 & 0.49 & 0.14 & 0.22 & 0.20 & 0.25 & 0.06 \\
\hline & Gasoline vehicle & 0.21 & $<0.01$ & $<0.01$ & 0.17 & 0.03 & 0.04 & 0.08 & 0.18 & 0.02 \\
\hline & Biomass burning & 0.00 & $<0.01$ & 0.32 & 0.10 & 0.02 & 0.10 & 0.03 & 0.08 & 0.03 \\
\hline & Total estimated & 1.37 & 1.52 & 0.41 & 1.22 & 0.32 & 0.54 & 0.47 & 0.69 & 0.17 \\
\hline & Total measured & 1.47 & 1.59 & 0.44 & 1.26 & 0.34 & 0.57 & 0.49 & 0.71 & 0.18 \\
\hline \multirow[t]{8}{*}{ Task IV } & Incheon PAH source & PHEN & FLRTH & $\mathrm{BaA}$ & $\begin{array}{r}\mathrm{B}[\mathrm{b}+ \\
\mathrm{j}] \mathrm{F}\end{array}$ & $\mathrm{BkF}$ & $\mathrm{BaP}$ & I123P & BghiP & ANTHN \\
\hline & Coal combustion & 0.22 & 1.11 & 0.06 & 0.41 & 0.10 & 0.16 & 0.17 & 0.28 & 0.02 \\
\hline & Oil combustion & 1.20 & 0.70 & 0.02 & 0.39 & 0.10 & $<0.01$ & 0.03 & $<0.01$ & 0.01 \\
\hline & Diesel vehicle & 0.17 & 0.13 & 0.11 & 0.69 & 0.17 & 0.20 & 0.18 & 0.22 & 0.02 \\
\hline & Gasoline vehicle & 0.12 & $<0.01$ & 0.08 & 0.01 & $<0.01$ & 0.09 & 0.11 & 0.20 & 0.07 \\
\hline & Biomass burning & $<0.01$ & 0.61 & 0.49 & 0.47 & 0.13 & 0.37 & 0.13 & 0.16 & 0.06 \\
\hline & Total estimated & 1.71 & 2.55 & 0.77 & 1.97 & 0.50 & 0.82 & 0.61 & 0.86 & 0.18 \\
\hline & Total measured & 1.71 & 2.59 & 0.77 & 1.98 & 0.50 & 0.82 & 0.62 & 0.87 & 0.18 \\
\hline \multirow[t]{9}{*}{ Task V } & Seoul HM source & As & $\mathrm{Cd}$ & Co & $\mathrm{Mn}$ & $\mathrm{Ni}$ & $\mathrm{Pb}$ & $\mathrm{Ti}$ & V & $\mathrm{Zn}$ \\
\hline & Soil resuspension & 0.28 & 0.11 & 0.25 & 10.39 & 0.57 & $<0.01$ & 31.07 & 0.33 & 11.69 \\
\hline & Oil combustion & 0.14 & 0.01 & 0.04 & 2.38 & 1.56 & 1.41 & 2.92 & 2.01 & 10.18 \\
\hline & Coal combustion & 3.53 & 0.11 & 0.01 & 0.44 & 0.16 & 3.60 & 3.51 & 0.18 & $<0.01$ \\
\hline & Traffic related & $<0.01$ & $<0.01$ & 0.33 & 20.95 & 1.14 & 14.50 & 26.28 & 1.28 & 85.29 \\
\hline & Incineration & $<0.01$ & 0.61 & 0.08 & 5.68 & 0.97 & 9.59 & 0.06 & 0.34 & 25.86 \\
\hline & Marine aerosol & $<0.01$ & 0.00 & 0.01 & 0.33 & $<0.01$ & 1.84 & 3.18 & $<0.01$ & $<0.01$ \\
\hline & Total estimated & 3.95 & 0.84 & 0.72 & 40.18 & 4.41 & 30.94 & 67.03 & 4.14 & 133.02 \\
\hline & Total measured & 4.09 & 1.21 & 0.75 & 41.13 & 5.40 & 34.04 & 67.70 & 4.23 & 137.60 \\
\hline \multirow[t]{5}{*}{ Task VI } & Incheon HM source & As & $\mathrm{Cd}$ & Co & $\mathrm{Mn}$ & $\mathrm{Ni}$ & $\mathrm{Pb}$ & $\mathrm{Ti}$ & $\mathrm{V}$ & $\mathrm{Zn}$ \\
\hline & Soil resuspension & 0.33 & 0.03 & 0.16 & 46.35 & 0.00 & $<0.01$ & 63.97 & 1.35 & 0.57 \\
\hline & Oil combustion & 0.38 & 0.01 & $<0.01$ & 7.93 & 2.80 & $<0.01$ & $<0.01$ & 9.65 & 0.47 \\
\hline & Coal combustion & 5.01 & $<0.01$ & $<0.01$ & $<0.01$ & $<0.01$ & 5.31 & 7.47 & 1.01 & $<0.01$ \\
\hline & Traffic related & 0.60 & 0.26 & $<0.01$ & 1.44 & 0.18 & 8.40 & 12.88 & $<0.01$ & 81.70 \\
\hline
\end{tabular}


Table 3 (continued)

\begin{tabular}{|c|c|c|c|c|c|c|c|c|c|}
\hline Incineration & 0.55 & 0.93 & $<0.01$ & 15.53 & 2.79 & 20.87 & 8.80 & $<0.01$ & $<0.01$ \\
\hline Industry & $<0.01$ & $<0.01$ & 0.82 & 1.51 & 2.84 & 16.40 & $<0.01$ & $<0.01$ & 2.19 \\
\hline Marine aerosol & $<0.01$ & $<0.01$ & 0.02 & 1.11 & 0.00 & 0.06 & 1.28 & 0.24 & 9.95 \\
\hline Total estimated & 6.87 & 1.23 & 1.01 & 73.87 & 8.61 & 51.04 & 94.40 & 12.24 & 94.89 \\
\hline Total measured & 6.88 & 1.34 & 1.05 & 76.16 & 10.16 & 57.23 & 98.60 & 12.24 & 96.40 \\
\hline
\end{tabular}

estimation was not performed because the runs were often aborted during computation for unknown reasons. Consequently, six and five factors were extracted from the VOC and PAH data, respectively, for each city. Six and seven factors were extracted from the HM data for Seoul and Incheon, respectively. A summary of the input data settings for the six PMF tasks and the diagnostics for error estimations is presented in Table S11. The number of variables included in PMF modeling was based on the signal to noise ratio $(\mathrm{S} / \mathrm{N})$; each species was categorized as "bad" $(\mathrm{S} / \mathrm{N}<2.0)$, "weak" $(2.0 \leq \mathrm{S} / \mathrm{N}<3.0)$, and "strong" $(\mathrm{S} / \mathrm{N} \geq 3.0)$. In this study, each PMF solution was adopted from the base runs because there
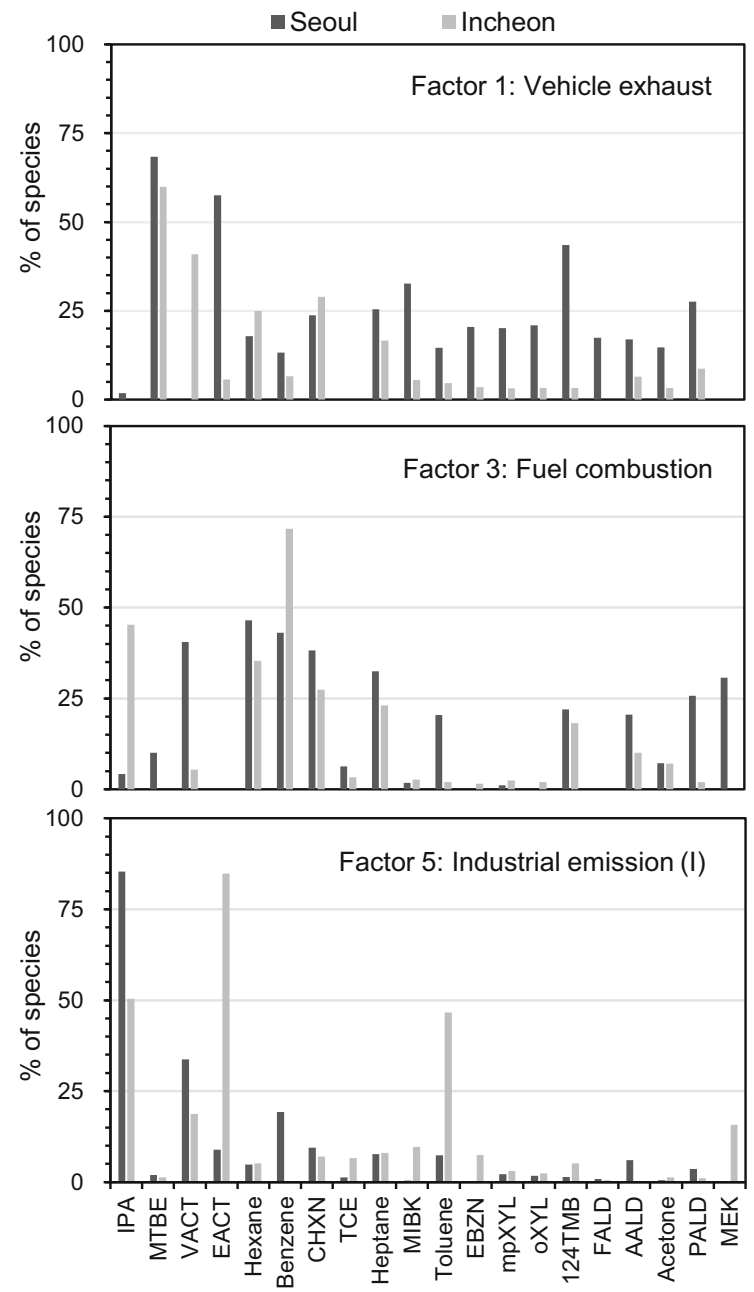

Fig. 4 Source profiles of VOCs in Seoul and Incheon were no significant changes ( $d Q \leq 0.5 \%)$ in the pattern of factors between the base runs and Fpeak runs.

Source profiles extracted from VOCs, PAHs, and trace elements are shown in Figs. 4, 5, and 6, respectively. The source profile is the chemical composition of emission sources. It is expressed as either the absolute concentration of each species apportioned to the factor or the percentage of each species apportioned to the factor relative to the total concentration of the species. For simplicity, the source profiles were expressed as percentages in this study. Overall, the source profiles for Seoul and Incheon were very similar; however, each factor's relative contribution was not identical.
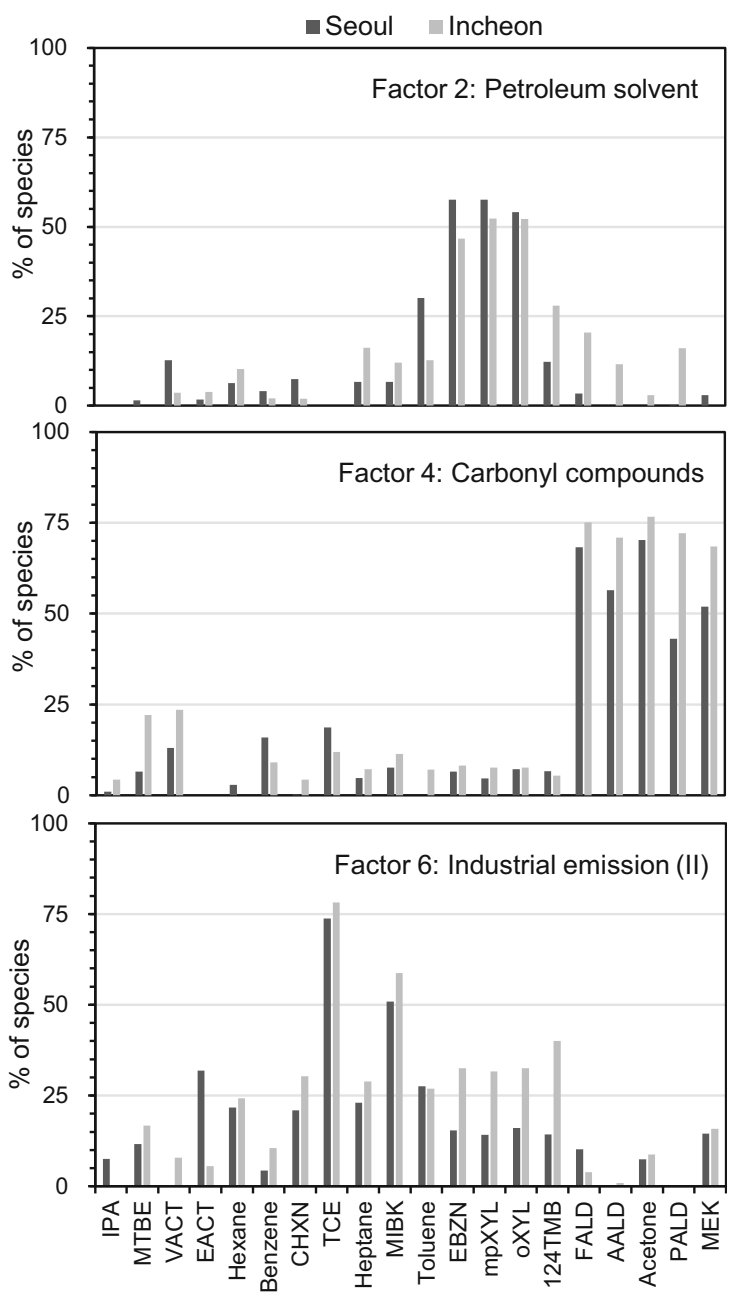

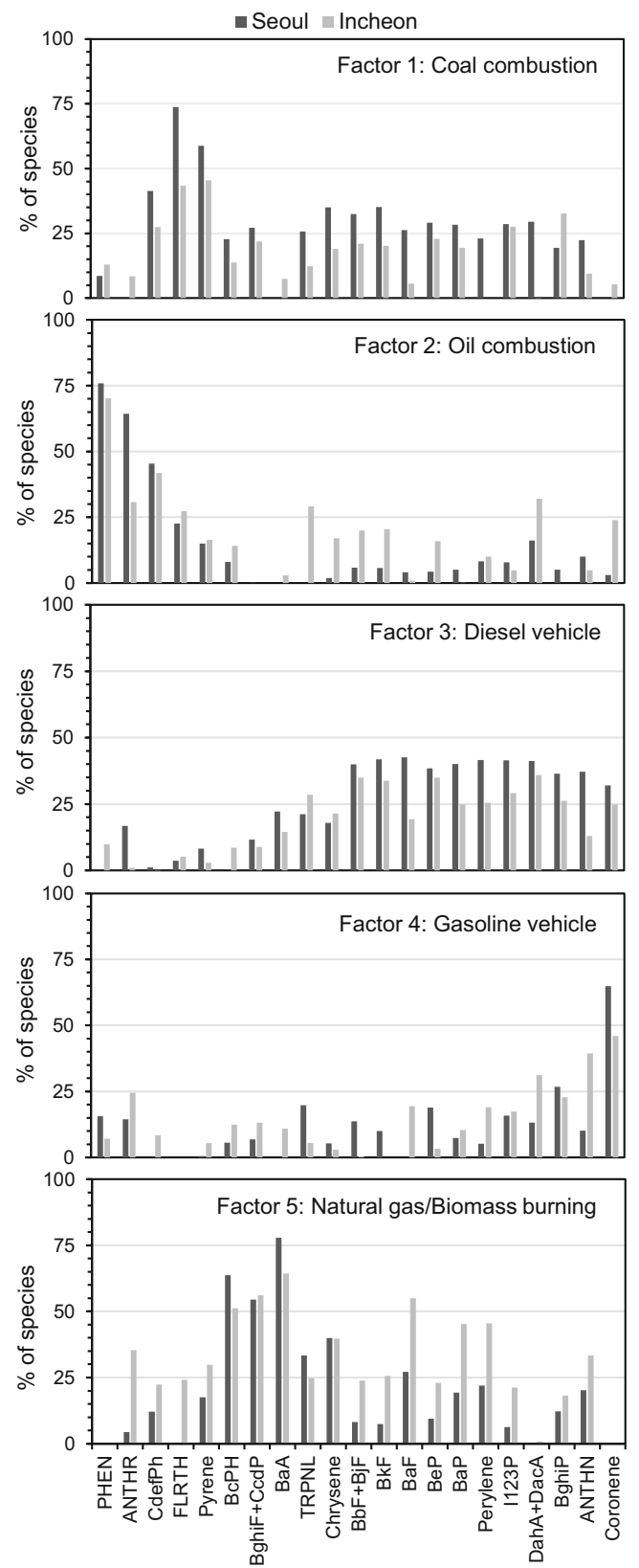

Fig. 5 Source profiles of PAHs in Seoul and Incheon

Consequently, each city's source profile for one group of HAPs is presented in each of the three figures. Additionally, the time series of source contributions for each HAP group and city estimated by PMF modeling are presented in Figs. S6-S11. Factors were initially characterized to obtain an easily interpretable factor, regardless of the order of their appearance in the PMF results.

VOC source profiles The source profiles of VOC data consisted of 20 variables (Fig. 4). The first factor was named as "vehicle exhaust" because MTBE exhibited the highest contribution (68.4\% and 59.9\% in Seoul and Incheon, respectively, hereinafter). MTBE is blended into gasoline as an anti-
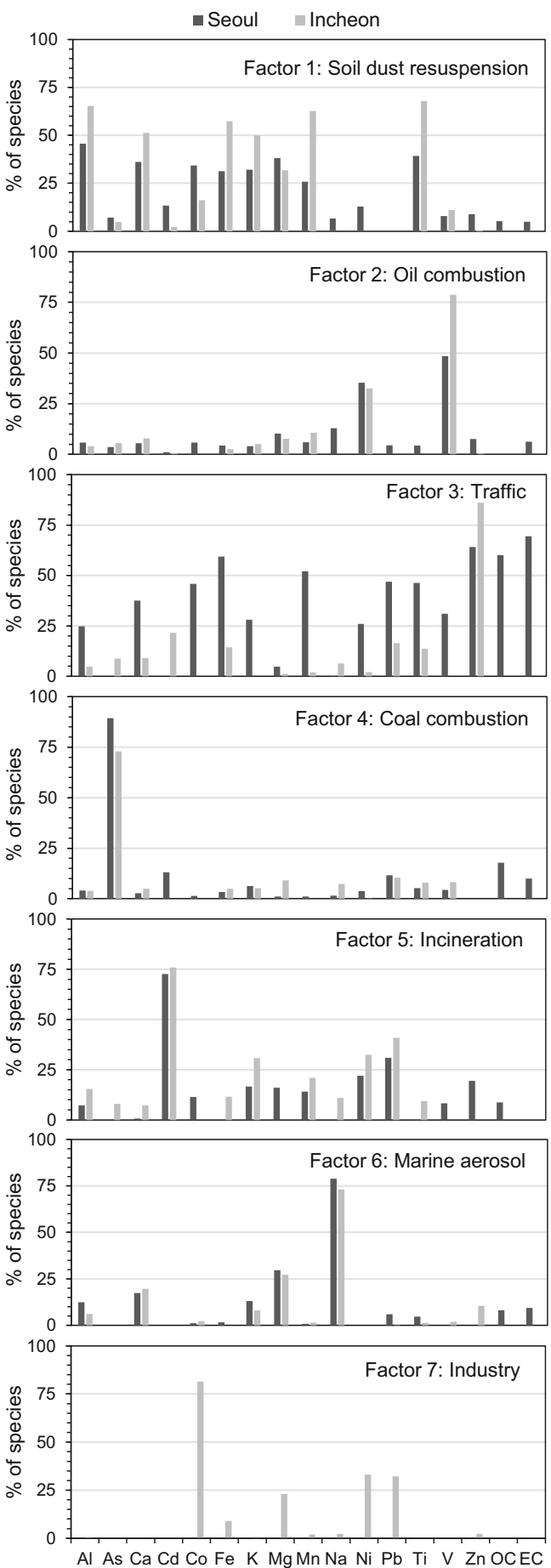

Fig. 6 Source profiles of HMs in Seoul and Incheon

knocking agent (Vainiotalo et al. 1998), and is a good indicator of vehicle exhaust in urban areas (Hsieh et al. 2006). A high contribution (43.5\% in Seoul) of 1,2,4-trimethylbenzene (124TMB) supported the relationship between this factor and vehicle exhaust (Bari and Kindzierski 2018; $\mathrm{Na}$ et al. 2002). However, the first factor seems to be partially associated with industrial sources because ethyl acetate (EACT) in Seoul and vinyl acetate (VACT) in Incheon had the second-highest 
contributions to this factor. The dominant species of the second factor were ethylbenzene (EBZN) and xylenes (52\%, $57 \%$ ). These two aromatics are the components of paint thinners and varnishes used in architectural coatings and the printing, rubber, and leather industries (Bari and Kindzierski 2018; Kim et al. 2020; Xiong et al. 2020); therefore, this source was called "petroleum solvent" to distinguish it from chlorinebased and carbonyl solvents. The third factor had high contributions of benzene $(43.5 \%, 71.7 \%)$, hexane $(46.5 \%, 35.4 \%)$, and cyclohexane $(38.2 \%, 27.4 \%)$. We named this factor "fuel combustion" because these VOCs are associated with combustion sources (Bari and Kindzierski 2018; Xiong et al. 2020). This factor may be related to the evaporative emission of petroleum under high-temperature conditions (Xiang et al. 2012). However, the time series of this factor (Figs. S6 and S7) showed that the contributions were higher in cold seasons than warm seasons, indicating a correlation with residential heating. The fourth factor was mainly associated with carbonyl compounds (43.1\%-76.7\%), which have atmospheric behavior and emission sources that differ from other VOCs. The fifth and sixth factors had contributions from organic solvents widely used in industry, but the data indicated two independent factors. The fifth factor was associated with isopropyl alcohol (IPA), EACT, VACT, and toluene, whereas the sixth factor was associated with TCE, methyl isobutyl ketone (MIBK), toluene, EBZN, and xylenes. Significant amounts of these substances were discharged from Incheon and SBNIC as fugitive emissions (Table S12), according to the Korean pollutant release and transfer registry (PRTR) data (KNIC 2015), the atmospheric levels of these industrial solvents in Seoul seem to be affected by the transport or dispersion of emissions in Incheon and the SBNIC. Therefore, the two factors were named "industrial emission (I) and (II)."

PAH source profiles As shown in Fig. 5, the source profiles of PAH data consisted of 21 variables encompassing PAHs with 3-6 rings. The first factor had high contributions from coal combustion markers, such as FLRTH $(73.8 \%, 43.4 \%)$ and pyrene $(58.8 \%, 45.4 \%)$ (Khalili et al. 1995; Larsen and Baker 2003; Wang et al. 2014), and moderate contributions from chrysene, benzo(k)fluoranthene (BkF), I123P. Diagnostic ratios for FLRTH/(FLRTH+pyrene) and I123P/ (I123P+BghiP) of $>0.5$ have been used to identify coal combustion (De La Torr-Roche et al. 2009; Yunker et al. 2002): mean values of these two ratios for the first factor were 0.66 and 0.58 , respectively. Therefore, we named this factor "coal combustion." According to the time series data (Figs. S8 and S9), the source contributions were higher in cold seasons than warm seasons, indicating that domestic coal-fired power plants and transboundary transport were affecting sources. Phenanthrene (PHEN) and 3-4 ring PAHs were distinctly abundant in the second factor. Low molecular weight (MW) PAHs are indicators of petrogenic sources, including crude oil and petroleum residues (Liu et al. 2018; Ravindra et al. 2008; Taghvaee et al. 2018; Wang et al. 2014; Wang et al. 2016). Low MW PAHs have also been attributed to oil combustion sources (Agudel-Castaneda and Teixeira 2014; Chen et al. 2016; Larsen and Baker 2003; Mishra et al. 2016) and to the evaporation of petroleum in warm seasons (Mishra et al. 2016; Wang et al. 2016). Petroleum combustion has often been identified based on the diagnostic ratios for FLRTH/(FLRTH+ pyrene) of 0.4-0.5 (De La Torr-Roche et al. 2009) and I123/(I123P+BghiP) of 0.2-0.5 (Yunker et al. 2002). A ratio of $\mathrm{BaA} /(\mathrm{BaA}+$ chrysene) less than 0.2 was also suggested as an index for petrogenic sources of PAHs; while the ratio of 0.2-0.35 indicate coal combustion (Akyüz and Çabuk 2010). In this study, those ratios were found to be $0.58,0.48$, and 0.09 , respectively. Although these values do not fully meet the existing criteria, this factor was named "oil combustion" in consideration of the uncertainty of the diagnostic ratios (Tobiszewski and Namieśnik 2012). Temporal pattern of this factor was similar to that of coal combustion (Figs. S8 and S9), reflecting a relationship with fuel combustion during the heating period. The third factor was characterized as "diesel vehicle exhaust" because it was associated with 5-ring PAHs, encompassing BkF to BghiP. The source profiles of diesel and gasoline vehicles are often similar because they share some PAHs (Callén et al. 2014; Chen et al. 2016; Mishra et al. 2016; Ravindar et al. 2008). However, the relative abundance of benzofluoranthenes, I123P, and BghiP are greater in diesel emissions than gasoline exhaust (Agudel-Castaneda and Teixeira 2014; Larsen and Baker 2003; Liu et al. 2018; Khalili et al. 1995; Ravindra et al. 2008; Simcik et al. 1999; Taghvaee et al. 2018). The fourth factor overlapped the third factor in the four-factor solution, but it was an independent factor in the five-factor solution, implying that the two factors are derived from vehicle exhaust. Coronene exhibited the highest contribution $(64.9 \%, 45.9 \%)$ in the fourth factor. The contributions of anthanthrene, BghiP, I123P, and dibenzo[a,h]anthracene+dibenzo[a,c]anthracene $(\mathrm{DahA}+$ DacA) in the fourth factor were higher than those of benzofluoranthenes (tracers of diesel vehicles). Gasoline vehicles are sources of higher MW PAHs (Khalili et al. 1995; Miguel et al. 1998; Schauer et al. 2002). The time series of the third and fourth factors were alike, with no significant differences between the heating and non-heating periods (Figs. S8 and S9). Accordingly, this factor was named "gasoline exhaust," as in other studies (Chen et al. 2016; Khalili et al. 1995; Larsen and Baker 2003; Ravindra et al. 2008). Diagnostic ratios for $\mathrm{BaP} /(\mathrm{BaP}+$ chrysene $)$ of 0.5 and 0.7 have been suggested to identify diesel and gasoline emissions, respectively (Khalili et al. 1995; Ravindra et al. 2008). Our results for the third (diesel) and fourth (gasoline) factors were 0.51 and 0.60 , respectively, which are very close to the suggested values. Diesel emission was also characterized by a ratio for $\mathrm{I} 123 \mathrm{P} /(\mathrm{I} 123 \mathrm{P}+\mathrm{BghiP})$ of $0.35-0.70$ (Ravindra et al. 
2008): we found a value of 0.44 for the "diesel exhaust" factor, which fall within the limits. In addition, ratios for $\mathrm{BaA} /$ (BaA+chrysene) of $>0.35$ and $\mathrm{BaP} / \mathrm{BghiP}$ of $>0.6$ have been used to identify traffic emissions (Akyüz and Çabuk 2010; Chen et al. 2016; Tobiszewski and Namieśnik 2012), while our results (averages of the third and fourth factors) showed values of 0.36 and 0.62 , respectively. All these results support that the third and the fourth factors are certainly associated with vehicle emission sources. The fifth factor had the highest contribution of $\mathrm{BaA}$, followed by benzo[g,h,i]fluoranthene+ cyclopenta[c,d]pyrene (BghiF+CcdP), benzo[c]phenanthrene $(\mathrm{BcPH})$, and chrysene. Triphenylene (TRPNL), benzo[a]fluoranthene $(\mathrm{BaF}), \mathrm{BaP}$ and perylene moderately contributed to this factor. $\mathrm{BaA}$ and chrysene are indicators of natural gas combustion (Callén et al. 2014; Mishra et al. 2016; Simcik et al. 1999; Taghvaee et al. 2018); however, wood and biomass burning are also sources of BaA, chrysene, and $\mathrm{BaP}$ (Agudel-Castaneda and Teixeira 2014; Taghvaee et al. 2018; Wang et al. 2014). Therefore, we named this factor "natural gas/biomass burning." Town gas is produced from naphtha and natural gas and is a primary residential fuel in Seoul and Incheon. Wood/agricultural burning in the outskirts of the SIMA during cold seasons was identified by PMF modeling as a significant PM source in Seoul (Park et al. 2019). The contributions of this factor were significantly higher in the heating period compared to the non-heating period (Figs. S8 and S9). There are few diagnostic ratio data for natural gas, and the ratios for the combustion of biomass (wood and grass) have been reported in the same category as coal combustion in the literature (Tobiszewski and Namieśnik 2012). Therefore, it is difficult to evaluate the "natural gas/biomass burning" factor with respect to the PAH diagnostic ratios.

HM source profiles The source profiles of trace elements, including six toxic HMs, and OC/EC are shown in Fig. 6. In this study, $\mathrm{OC} / \mathrm{EC}$ were analyzed from $\mathrm{PM}_{2.5}$ samples which were collected simultaneously along with the TSP samples. The first factor was named "soil dust resuspension" because the soil

Table 4 Cancer risks posed by the top 25 HAPs in Seoul and Incheon

\begin{tabular}{|c|c|c|c|c|c|c|c|c|c|}
\hline \multicolumn{5}{|l|}{ Seoul } & \multicolumn{5}{|c|}{ Incheon } \\
\hline Rank & HAP & Mean cancer risk & Mean concentration & Group & Rank & HAP & Mean cancer risk & Mean concentration & Group \\
\hline 1 & $\mathrm{BaP}$ & $5.0 \mathrm{E}-05$ & $0.57 \mathrm{ng} / \mathrm{m}^{3}$ & PAH & 1 & $\mathrm{BaP}$ & 7.1E-05 & $0.82 \mathrm{ng} / \mathrm{m}^{3}$ & PAH \\
\hline 2 & FALD & $4.8 \mathrm{E}-05$ & $3.70 \mu \mathrm{g} / \mathrm{m}^{3}$ & VOC & 2 & FALD & $4.8 \mathrm{E}-05$ & $3.67 \mu \mathrm{g} / \mathrm{m}^{3}$ & VOC \\
\hline 3 & As & $1.8 \mathrm{E}-05$ & $4.09 \mathrm{ng} / \mathrm{m}^{3}$ & HM & 3 & As & $3.0 \mathrm{E}-05$ & $6.88 \mathrm{ng} / \mathrm{m}^{3}$ & HM \\
\hline 4 & Benzene & $1.2 \mathrm{E}-05$ & $1.55 \mu \mathrm{g} / \mathrm{m}^{3}$ & VOC & 4 & Benzene & $1.5 \mathrm{E}-05$ & $1.98 \mu \mathrm{g} / \mathrm{m}^{3}$ & VOC \\
\hline 5 & EBZN & $8.3 \mathrm{E}-06$ & $3.33 \mu \mathrm{g} / \mathrm{m}^{3}$ & VOC & 5 & TCE & $1.0 \mathrm{E}-05$ & $2.50 \mu \mathrm{g} / \mathrm{m}^{3}$ & VOC \\
\hline 6 & AALD & $8.1 \mathrm{E}-06$ & $3.68 \mu \mathrm{g} / \mathrm{m}^{3}$ & VOC & 6 & $\mathrm{Co}$ & $9.4 \mathrm{E}-06$ & $1.05 \mathrm{ng} / \mathrm{m}^{3}$ & HM \\
\hline 7 & Co & $6.7 \mathrm{E}-06$ & $0.75 \mathrm{ng} / \mathrm{m}^{3}$ & HM & 7 & $\mathrm{BbF}$ & $8.6 \mathrm{E}-06$ & $0.99 \mathrm{ng} / \mathrm{m}^{3}$ & РAH \\
\hline 8 & DahA & $5.9 \mathrm{E}-06$ & $0.07 \mathrm{ng} / \mathrm{m}^{3}$ & PAH & 8 & $\mathrm{BjF}$ & $8.6 \mathrm{E}-06$ & $0.99 \mathrm{ng} / \mathrm{m}^{3}$ & РAH \\
\hline 9 & $\mathrm{BbF}$ & $5.5 \mathrm{E}-06$ & $0.63 \mathrm{ng} / \mathrm{m}^{3}$ & PAH & 9 & AALD & $8.0 \mathrm{E}-06$ & $3.63 \mu \mathrm{g} / \mathrm{m}^{3}$ & VOC \\
\hline 9 & $\mathrm{BjF}$ & $5.5 \mathrm{E}-06$ & $0.63 \mathrm{ng} / \mathrm{m}^{3}$ & PAH & 9 & DahA & 7.4E-06 & $0.09 \mathrm{ng} / \mathrm{m}^{3}$ & PAH \\
\hline 11 & I123P & $4.3 \mathrm{E}-06$ & $0.49 \mathrm{ng} / \mathrm{m}^{3}$ & PAH & 11 & EBZN & $6.8 \mathrm{E}-06$ & $2.72 \mu \mathrm{g} / \mathrm{m}^{3}$ & VOC \\
\hline 12 & TCE & $4.1 \mathrm{E}-06$ & $1.00 \mu \mathrm{g} / \mathrm{m}^{3}$ & VOC & 12 & $\mathrm{BaA}$ & $6.7 \mathrm{E}-06$ & $0.77 \mathrm{ng} / \mathrm{m}^{3}$ & PAH \\
\hline 13 & $\mathrm{BaA}$ & $3.8 \mathrm{E}-06$ & $0.44 \mathrm{ng} / \mathrm{m}^{3}$ & PAH & 13 & I123P & $5.4 \mathrm{E}-06$ & $0.62 \mathrm{ng} / \mathrm{m}^{3}$ & PAH \\
\hline 14 & CTTC & $3.4 \mathrm{E}-06$ & $0.56 \mu \mathrm{g} / \mathrm{m}^{3}$ & VOC & 14 & CcdP & $4.5 \mathrm{E}-06$ & $0.52 \mathrm{ng} / \mathrm{m}^{3}$ & PAH \\
\hline 15 & $\mathrm{BkF}$ & $2.9 \mathrm{E}-06$ & $0.34 \mathrm{ng} / \mathrm{m}^{3}$ & PAH & 15 & $\mathrm{BkF}$ & $4.4 \mathrm{E}-06$ & $0.50 \mathrm{ng} / \mathrm{m}^{3}$ & PAH \\
\hline 16 & CcdP & $2.7 \mathrm{E}-06$ & $0.31 \mathrm{ng} / \mathrm{m}^{3}$ & PAH & 16 & CLFM & $4.0 \mathrm{E}-06$ & $0.17 \mu \mathrm{g} / \mathrm{m}^{3}$ & VOC \\
\hline 17 & $\mathrm{Cd}$ & $2.2 \mathrm{E}-06$ & $1.21 \mathrm{ng} / \mathrm{m}^{3}$ & $\mathrm{HM}$ & 17 & CTTC & $3.3 \mathrm{E}-06$ & $0.55 \mu \mathrm{g} / \mathrm{m}^{3}$ & VOC \\
\hline 18 & CLFM & $1.8 \mathrm{E}-06$ & $0.08 \mu \mathrm{g} / \mathrm{m}^{3}$ & VOC & 18 & 12DCE & $3.2 \mathrm{E}-06$ & $0.12 \mu \mathrm{g} / \mathrm{m}^{3}$ & VOC \\
\hline 19 & ANTHN & $1.6 \mathrm{E}-06$ & $0.18 \mathrm{ng} / \mathrm{m}^{3}$ & PAH & 19 & $\mathrm{Cd}$ & $2.4 \mathrm{E}-06$ & $1.34 \mathrm{ng} / \mathrm{m}^{3}$ & HM \\
\hline 20 & 12DCE & $1.3 \mathrm{E}-06$ & $0.05 \mu \mathrm{g} / \mathrm{m}^{3}$ & VOC & 20 & $12 \mathrm{DCP}$ & $2.4 \mathrm{E}-06$ & $0.24 \mu \mathrm{g} / \mathrm{m}^{3}$ & VOC \\
\hline 21 & $\mathrm{Ni}$ & $1.3 \mathrm{E}-06$ & $5.40 \mathrm{ng} / \mathrm{m}^{3}$ & $\mathrm{HM}$ & 21 & $\mathrm{Ni}$ & $2.4 \mathrm{E}-06$ & $10.16 \mathrm{ng} / \mathrm{m}^{3}$ & $\mathrm{HM}$ \\
\hline 22 & $12 \mathrm{DCP}$ & $1.2 \mathrm{E}-06$ & $0.12 \mu \mathrm{g} / \mathrm{m}^{3}$ & VOC & 22 & ANTHN & $1.6 \mathrm{E}-06$ & $0.18 \mathrm{ng} / \mathrm{m}^{3}$ & PAH \\
\hline 23 & Chrysene & 7.2E-07 & $0.83 \mathrm{ng} / \mathrm{m}^{3}$ & PAH & 23 & Chrysene & $1.2 \mathrm{E}-06$ & $1.39 \mathrm{ng} / \mathrm{m}^{3}$ & PAH \\
\hline 24 & DacA & $5.9 \mathrm{E}-07$ & $0.07 \mathrm{ng} / \mathrm{m}^{3}$ & PAH & 24 & $\mathrm{Cr}(\mathrm{VI})$ & $1.2 \mathrm{E}-06$ & $0.10 \mathrm{ng} / \mathrm{m}^{3}$ & $\mathrm{HM}$ \\
\hline 25 & $\mathrm{~Pb}$ & 4.1E-07 & $34.04 \mathrm{ng} / \mathrm{m}^{3}$ & HM & 25 & DacA & $7.4 \mathrm{E}-07$ & $0.09 \mathrm{ng} / \mathrm{m}^{3}$ & PAH \\
\hline$\Sigma \mathrm{CR}$ & & $2.0 \mathrm{E}-04$ & & & $\Sigma \mathrm{CR}$ & & 2.7E-04 & & \\
\hline
\end{tabular}


components (e.g., $\mathrm{Al}, \mathrm{Ca}, \mathrm{Fe}, \mathrm{K}, \mathrm{Mg}, \mathrm{Mn}$, and $\mathrm{Ti}$ ) had high contributions (Chow 1995; Tsai et al. 2020). The second factor was named "oil combustion" because of high contributions of $\mathrm{V}$ and $\mathrm{Ni}$, markers of the combustion of diesel and residual oils (Belis et al. 2013; Chow 1995; Park et al. 2019). The third factor was characterized as "coal combustion," owing to the high contribution of As (Chow 1995; Tsai et al. 2010; Vejahati et al. 2010). The profiles of the fourth factor exhibited high contributions from $\mathrm{Zn}, \mathrm{Fe}, \mathrm{Mn}, \mathrm{OC}$, and $\mathrm{EC}$, for which the most common source in urban areas is traffic pollution (Park et al. 2019). $\mathrm{Zn}$ is emitted from the lubricating oil of diesel vehicles (Belis et al. 2013; Zhou et al. 2009), and Fe is found in the catalyst of gasoline cars (Cesari et al. 2016; Zhao and Hopke 2004). Fe and Zn are also markers of brake and tire wear (Hjortenkrans et al. 2007; Napier et al. 2008). Therefore, we named this factor "traffic" to encompass vehicle exhaust and tire/brake wear. The fifth factor had the highest contributions of $\mathrm{Cd}(72.6 \%, 75.8 \%)$, followed by $\mathrm{Pb}(46.9 \%, 40.9 \%)$, which are markers for the "incineration" of municipal wastes (Belis et al. 2013; Chow 1995; Park et al.
2019). $\mathrm{Na}$ and $\mathrm{Mg}$ were the first- and the second-abundant elements in the sixth factor, named "marine aerosol." The seventh factor was derived only from Incheon data, and it was named "industry." It differed from the fourth factor, having high contributions of $\mathrm{Co}, \mathrm{Ni}$, and $\mathrm{Pb}$. Industries in the SIMA are likely sources because Co is used in rechargeable batteries, super-alloys, paint, and petrochemical industrial processes.

We calculated the contributions of each source to HAP concentrations after identifying the sources. Examples of major HAPs in Seoul and Incheon are presented in Table 4. The PMF model accounted for $98.1 \%$ and $99.2 \%$ of the total concentrations of the 20 VOCs used in the modeling of the Seoul and Incheon data, respectively. The PMF model explained 100.2\% and $99.6 \%$ of the total concentrations of the $21 \mathrm{PAHs}$ for the two cities, respectively, whereas it underestimated the seven toxic HMs (93.8\% for both cities). Good correlations between estimated and measured values were obtained for most HAPs; $\mathrm{R}^{2}$ values close to one, and the slopes and intercepts of regressions were close to one and zero, respectively.

Table 5 Source-specific cancer and non-cancer risks in Seoul and Incheon

\begin{tabular}{|c|c|c|c|c|c|c|}
\hline \multirow[t]{3}{*}{ HAP Source } & \multicolumn{6}{|c|}{ Cancer risk (CR, per million) and contribution (\%) by each source } \\
\hline & \multicolumn{3}{|l|}{ Seoul } & \multicolumn{3}{|l|}{ Incheon } \\
\hline & Heating Period $^{\text {a) }}$ & Non-heating Period ${ }^{b)}$ & Annual & Heating period & Non-heating period & Annual \\
\hline Traffic related source & $55.8(29.3 \%)$ & $39.1(23.1 \%)$ & $53.8(29.1 \%)$ & $60.9(17.3 \%)$ & $48.1(29.5 \%)$ & $49.2(19.9 \%)$ \\
\hline Fossil fuel combustion & $65.6(34.4 \%)$ & $26.1(15.4 \%)$ & $50.7(27.4 \%)$ & $109.8(31.1 \%)$ & $24.6(15.1 \%)$ & $65.9(26.7 \%)$ \\
\hline Petroleum solvent & $5.7(3.0 \%)$ & $8.1(4.8 \%)$ & $6.5(3.5 \%)$ & $11.9(3.4 \%)$ & $14.8(9.1 \%)$ & $13.1(5.3 \%)$ \\
\hline Industrial emission & $12.9(6.8 \%)$ & $12.4(7.3 \%)$ & $12.7(6.9 \%)$ & $28.8(8.2 \%)$ & $18.2(11.2 \%)$ & $23.2(9.4 \%)$ \\
\hline Natural gas/Biomass burning & $21.6(11.3 \%)$ & $3.4(2.0 \%)$ & $15.1(8.2 \%)$ & $90.4(25.6 \%)$ & $9.1(5.6 \%)$ & $46.5(18.8 \%)$ \\
\hline Incineration & $2.7(1.4 \%)$ & $1.3(0.8 \%)$ & $2.2(1.2 \%)$ & $7.8(2.2 \%)$ & $2.4(1.5 \%)$ & $5.0(2.0 \%)$ \\
\hline Carbonyl compounds & $21.8(11.4 \%)$ & $76.2(45.0 \%)$ & $39.9(21.6 \%)$ & $38.2(10.8 \%)$ & $44.6(27.4 \%)$ & $40.9(16.6 \%)$ \\
\hline Soil dust resuspension & $4.5(2.4 \%)$ & $2.5(1.5 \%)$ & $3.8(2.1 \%)$ & $4.9(1.4 \%)$ & $1.0(0.6 \%)$ & $2.9(1.2 \%)$ \\
\hline Marine aerosol & $<0.1(0.1 \%)$ & $<0.1(0.1 \%)$ & $<0.1(0.1 \%)$ & $0.2(<0.1 \%)$ & $0.2(0.1 \%)$ & $0.2(0.1 \%)$ \\
\hline$\sum \mathrm{CR}$ & $190.6(100 \%)$ & $169.2(100 \%)$ & $184.8(100 \%)$ & $352.9(100 \%)$ & $163.0(100 \%)$ & $246.9(100 \%)$ \\
\hline \multirow[t]{3}{*}{ HAP Source } & \multicolumn{6}{|c|}{ Non-cancer risk (HQ) and contribution (\%) by each source } \\
\hline & \multicolumn{3}{|l|}{ Seoul } & \multicolumn{3}{|l|}{ Incheon } \\
\hline & Heating period & Non-heating period & Annual & Heating period & Non-heating period & Annual \\
\hline Traffic related source & $0.54(21.8 \%)$ & $0.52(18.0 \%)$ & $0.56(24.3 \%)$ & $0.29(5.2 \%)$ & $0.43(13.1 \%)$ & $0.34(7.8 \%)$ \\
\hline Fossil fuel combustion & $0.71(28.6 \%)$ & $0.41(14.2 \%)$ & $0.60(22.8 \%)$ & $1.17(21.0 \%)$ & $0.38(11.6 \%)$ & $0.78(17.8 \%)$ \\
\hline Petroleum solvent & $0.05(2.0 \%)$ & $0.07(2.4 \%)$ & $0.06(2.3 \%)$ & $0.16(2.9 \%)$ & $0.21(6.4 \%)$ & $0.18(4.1 \%)$ \\
\hline Industrial emission & $0.47(19.0 \%)$ & $0.55(19.0 \%)$ & $0.50(19.0 \%)$ & $2.02(36.3 \%)$ & $1.19(36.4 \%)$ & $1.61(36.8 \%)$ \\
\hline Natural gas/Biomass burning & $0.08(3.2 \%)$ & $0.01(0.3 \%)$ & $0.05(1.9 \%)$ & $0.36(6.5 \%)$ & $0.04(1.2 \%)$ & $0.19(4.4 \%)$ \\
\hline Incineration & $0.20(8.1 \%)$ & $0.09(3.1 \%)$ & $0.16(6.1 \%)$ & $0.55(9.9 \%)$ & $0.17(5.2 \%)$ & $0.35(8.0 \%)$ \\
\hline Carbonyl compounds & $0.33(13.3 \%)$ & $1.17(40.5 \%)$ & $0.61(23.2 \%)$ & $0.67(12.0 \%)$ & $0.78(23.8 \%)$ & $0.72(16.5 \%)$ \\
\hline Soil dust resuspension & $0.09(3.6 \%)$ & $0.05(1.7 \%)$ & $0.08(3.0 \%)$ & $0.33(5.9 \%)$ & $0.07(2.1 \%)$ & $0.19(4.3 \%)$ \\
\hline Marine aerosol & $0.01(0.4 \%)$ & $0.02(0.7 \%)$ & $0.01(0.4 \%)$ & $0.01(0.2 \%)$ & $0.01(0.3 \%)$ & $0.01(0.2 \%)$ \\
\hline$\sum \mathrm{HQ}$ & $2.48(100 \%)$ & $2.89(100 \%)$ & $2.63(100 \%)$ & $5.56(100 \%)$ & $3.27(100 \%)$ & $4.37(100 \%)$ \\
\hline
\end{tabular}

a) Heating period: from November through March; b) Non-heating period: from April through October 


\section{Source-specific risk apportionment}

Using the information obtained from the health risks of individual HAPs (Section 3.3) and the source apportionment (Section 3.4), we calculated source-specific health risks. A total of six, five, and seven sources were identified for VOCs, PAHs, and HMs, respectively. The identified sources were relatively but not identical among the three groups and reflected the emission characteristics and atmospheric behavior of each HAP group. Therefore, we reclassified the sources by considering their nature and similarity as follows: Vehicle exhaust (for VOCs), gasoline and diesel vehicles (for PAHs), and traffic (for HMs) were grouped into a source named "traffic-related source." Fuel combustion (for VOCs) and oil and coal combustion (for both PAHs and HMs) were combined into a group named "fossil fuel combustion." Industrial emissions I and II (for VOCs) and industry (for HMs) were collectively named "industrial emissions." Consequently, sourcespecific risks were calculated for nine sources using all available risk-posing HAPs and their corresponding toxicity values, according to Eqs. (3), (6), and (7). Several studies have also applied this approach to find out which source may pose a greater risk to public health (Bari and Kindzierski 2017; Wu et al. 2009; Xiong et al. 2020). The risk apportionment from each of the nine sources was then divided between heating and non-heating periods for each city (Table 5).

The apportionment of source-specific cancer risks on an annual basis revealed that the most significant sources in Seoul were traffic $(29.1 \%)>$ fossil fuel combustion $(27.4 \%)$ $>$ carbonyl compounds (21.6\%), accounting for $78.1 \%$ of the $\sum \mathrm{CR}$. In Incheon, the apportionment was fossil fuel combustion $(26.7 \%)>$ traffic $(19.9 \%)>$ natural gas/biomass burning $(18.8 \%)>$ carbonyl compounds (16.6\%), accounting for $82.0 \%$ of the $\sum \mathrm{CR}$. However, with respect to the non-cancer risk, industrial emissions appeared to be the largest contributor (36.8\% of the $\sum \mathrm{HQ}$ ) in Incheon, whereas traffic remained the highest (24.3\%) in Seoul. As expected, combustion-related sources exhibited significantly higher risks in the heating period than in the non-heating period. However, an opposite trend was observed for petroleum solvents and carbonyls, reflecting the high dependency of these sources on the ambient temperature. Source-specific risks for traffic and industrial emissions did not show a clear pattern between the two periods. In general, traffic and industrial activities in urban areas are essentially constant. Contributions of soil dust and marine aerosols to health risks were negligible $\left(<3 \%\right.$ of the $\sum \mathrm{CR}$ and $5 \%$ of the $\Sigma H Q$ ).

\section{Conclusions}

The primary concern in the management of HAPs is the magnitude of risks incurred via inhalation exposure to which pollutants from what sources. This study was carried out to address this concern in the adjacent cities of Seoul and Incheon within Korea's largest urban area. Data obtained from intensive monitoring of a wide range of HAPs were used to investigate concentration levels spatially and temporally, apportion sources, and assess health risks. Overall, HAP concentrations in Incheon were higher than those in Seoul, despite its smaller population, which was attributed to more diverse emission sources in Incheon, a port city. However, the temporal variability of HAPs was typically higher than the spatial variability in each city. Combustion-related HAPs, such as PAHs, toxic HMs, and benzene, were at significantly higher levels during the heating period than during the non-heating period, but most VOCs (particularly carbonyls) exhibited the opposite trend.

In both cities, $\mathrm{BaP}$ had the highest cancer risk of any individual species, followed by FALD, As, and benzene. The cumulative cancer risks $(\Sigma \mathrm{CR})$ for 28 HAPs were $2.02 \times$ $10^{-4}$ and $2.71 \times 10^{-4}$ in Seoul and Incheon, respectively. These values are more than twice as high as the tolerable risk criterion proposed by the USEPA. The non-cancer risk was less significant than the cancer risk because the only HAP with an HQ > 1 was TCE in Incheon. Sources affecting HAP concentrations were identified by PMF modeling as follows: vehicle exhaust (gasoline and/or diesel), fossil fuel combustion (coal and/or oil), petroleum solvents, industrial emissions, carbonyls, incineration, natural gas/biomass burning, and soil dust. The three most important cancer risk sources in Seoul were traffic, fossil fuel combustion, and carbonyl compounds, accounting for $78.1 \%$ of the $\sum \mathrm{CR}$. In Incheon, the top four sources were fossil fuel combustion, traffic, natural gas/ biomass burning, and carbonyls, accounting for $82.0 \%$ of the $\sum \mathrm{CR}$. Industrial emissions were the largest contributor to non-cancer risk in Incheon, whereas traffic was the largest contributor in Seoul. Combustion-related sources all posed significantly higher risks in the heating period relative to the non-heating period. However, an opposite trend was observed for petroleum solvent and carbonyls, owing to the increased HAP concentrations from these sources in summer. There was no distinct trend in specific risks associated with traffic and industrial emissions between the two periods.

High priority should be given to controlling traffic pollution and using cleaner fuels in both cities to reduce the risks posed by HAPs in the SIMA. In addition, priority should be given to reducing carbonyl concentrations in Seoul and industrial emissions in Incheon. The industrial HAP emissions from large industrial complexes around the metropolitan area should also be prioritized. In addition, future studies are needed on the contribution of ship emission sources to HAP concentrations in Incheon, a port city. A practical way to reduce cancer risks is to establish new NAAQ standards for HAPs with high cancer risk or strengthen the existing emission standards for HAPs. Only two pollutants currently have NAAQ 
standards (as an annual average) in Korea: benzene $\left(5 \mu \mathrm{g} / \mathrm{m}^{3}\right)$ and $\mathrm{Pb}\left(0.5 \mu \mathrm{g} / \mathrm{m}^{3}\right)$. Therefore, it is necessary to introduce new standards for ambient levels of BaP and FALD because these two HAPs ranked high in terms of toxicity, abundance, and ubiquity. In Korea, the annual limit of ambient concentration of $\mathrm{PM}_{2.5}$ was strengthened in 2018 (from 25 to $15 \mu \mathrm{g} / \mathrm{m}^{3}$ ). However, it is further necessary to revise current emission standards from TSP to $\mathrm{PM}_{2.5}$ because particulate HAPs, such as PAHs and toxic HMs, are predominantly associated with $\mathrm{PM}_{2.5}$. Finally, HAP control measures within South Korea alone may not be the sole solution since the contributions of transboundary transport of HAPs from China and North Korea tend to be significant during cold seasons. Therefore, international cooperation and joint efforts to improve air quality in Northeast Asia are considered to be very important tasks.

Supplementary Information The online version contains supplementary material available at https://doi.org/10.1007/s11869-021-00986-z.

Authors' contribution Data curation, formal analysis, investigation, validation, visualization, writing - original draft [Min-Ji Kim and KyungMin Baek]. Software, investigation, data curation, funding acquisition [Jong-Bae Heo]. Investigation, software, validation [Jang-Pyo Cheong]; conceptualization, methodology, software, validation, writing - review and editing, Supervision, project administration, funding acquisition [Sung-Ok Baek].

Funding The monitoring portion of this study was supported by the National Institute of Environmental Research in Korea (Contract number 2013-142 and 2014-200). This study was also supported by the National Research Foundation of Korea (NRF) funded by the Korea government (MSIT) under grant NRF-2019R1A2C2007484.

\section{Declarations}

Conflict of interest The authors declare that they have no conflict of interest.

Open Access This article is licensed under a Creative Commons Attribution 4.0 International License, which permits use, sharing, adaptation, distribution and reproduction in any medium or format, as long as you give appropriate credit to the original author(s) and the source, provide a link to the Creative Commons licence, and indicate if changes were made. The images or other third party material in this article are included in the article's Creative Commons licence, unless indicated otherwise in a credit line to the material. If material is not included in the article's Creative Commons licence and your intended use is not permitted by statutory regulation or exceeds the permitted use, you will need to obtain permission directly from the copyright holder. To view a copy of this licence, visit http://creativecommons.org/licenses/by/4.0/.

\section{References}

Air Korea (2020) http://www.airkorea.or.kr/web/detailViewDown? pMENU_NO=125. Accessed 15 January 2020
Agency for Toxic Substances and Disease Registry (ATSDR) (2016) Toxicological profiles. https://www.atsdr.cdc.gov/substances/ indexAZ.asp. Accessed 10 August 2016

Akyüz M, Çabuk H (2010) Gaseparticle partitioning and seasonal variation of polycyclic aromatic hydrocarbons in the atmosphere of Zonguldak, Turkey. Sci Total Environ 408:5550-5558. https://doi. org/10.1016/j.scitotenv.2010.07.063

An Z, Jin Y, Li J, Li W, Wu W (2018) Impact of particulate air pollution on cardiovascular health. Curr Allergy Asthma Rep 18:15. https:// doi.org/10.1007/s11882-018-0768-8

Bae SY, Yi SM, Kim YP (2002) Temporal and spatial variations of the particle size distribution of PAHs and their dry deposition fluxes in Korea. Atmos Environ 36:5491-5500. https://doi.org/10.1016/ S1352-2310(02)00666-0

Baek KM, Kim MJ, Kim JY, Seo YK, Baek SO (2020a) Characterization and health impact assessment of hazardous air pollutants in residential areas near a large iron-steel industrial complex in Korea. Atmos Pollut. Res 11:1754-1766. https://doi.org/10.1016/j.apr.2020.07. 009

Baek KM, Kim MJ, Seo YK, Kang BW, Kim JH, Baek SO (2020b) Spatiotemporal variations and health implications of hazardous air pollutants in Ulsan, a multi-industrial city in Korea. Atmosphere 11: 1-23. https://doi.org/10.3390/atmos11050547

Baek KM, Seo YK, Kim JY, Baek SO (2019) Monitoring of particulate hazardous air pollutants and affecting factors in the largest industrial area in South Korea: The Sihwa-Banwol complex. Environ Eng Res 25:908-923. https://doi.org/10.4491/eer.2019.419

Baek SO, Suvarapu LN, Seo YK (2015) Occurrence and concentrations of toxic VOCs in the ambient air of Gumi, an electronics-industrial city in Korea. Sensors 15:19102-19123. https://doi.org/10.3390/ s150819102

Baklanov A, Molina LT, Gauss M (2016) Megacities, air quality and climate. Atmos Environ 126:235-249. https://doi.org/10.1016/j. atmosenv.2015.11.059

Bari MA, Kindzierski WB (2017) Concentrations, sources and human health risk of inhalation exposure to air toxics in Edmonton, Canada. Chemosphere 173:160-171. https://doi.org/10.1016/j. chemosphere.2016.12.157

Bari MA, Kindzierski WB (2018) Ambient volatile organic compounds (VOCs) in Calgary, Alberta: Sources and screening health risk assessment. Sci Total Environ 631-632:627-640. https://doi.org/10. 1016/j.scitotenv.2018.03.023

Belis CA, Karagulian F, Larsen BR, Hopke PK (2013) Critical review and meta-analysis of ambient particulate matter source apportionment using receptor models in Europe. Atmos Environ 69:94-108. https://doi.org/10.1016/j.atmosenv.2012.11.009

California Environmental Protection Agency (Cal EPA) (2018) Office of Environmental Health Hazard Assessment (OEHHA) Air Chemicals Database. https://oehha.ca.gov/air/chemicals. Accessed 15 August 2018

Callén MS, Iturmendi A, López JM (2014) Source apportionment of atmospheric PM2.5-bound polycyclic aromatic hydrocarbons by a PMF receptor model. Assessment of potential risk for human health. Environ Pollut 195:167-177. https://doi.org/10.1016/j.envpol.2014. 08.025

Cesari D, Donateo A, Conte M, Merico E, Giangreco A, Giangreco F, Contini D (2016) An inter-comparison of $\mathrm{PM}_{2.5}$ at urban and urban background sites: chemical characterization and source apportionment. Atmos Res 174-175:106-119 https://www.sciencedirect. com/science/article/pii/S0169809516300217

Chen YC, Chiang HC, Hsu CY, Yang TT, Lin TY, Chen MJ, Chen NT, Wu YS (2016) Ambient PM2.5-bound polycyclic aromatic hydrocarbons (PAHs) in Changhua County, central Taiwan: Seasonal variation, source apportionment and cancer risk assessment. Environ Pollut 218:372-382. https://doi.org/10.1016/j.envpol. 2016.07.016 
Cheruiyot NK, Lee WJ, Mwangi JK, Wang LC, Lin NH, Lin YC, Cao J, Zhang R, Chang-Chien GP (2015) An overview: Polycyclic aromatic hydrocarbon emissions from the stationary and mobile sources and in the ambient air. Aerosol Air Qual Res 15:2730-2762. https:// doi.org/10.4209/aaqr.2015.11.0627

Chow JC (1995) Measurement methods to determine compliance with ambient air quality standards for suspended particles. J Air Waste Manag Assoc 45:320-382. https://doi.org/10.1080/10473289.1995. 10467369

Dat ND, Chang MB (2017) Review on characteristics of PAHs in atmosphere, anthropogenic sources and control technologies. Sci Total Environ 609:682-693. https://doi.org/10.1016/j.scitotenv.2017.07. 204

Fox MA, Tran NL, Groopman JD, Burke TA (2004) Toxicological resources for cumulative risk: An example with hazardous air pollutants. Regul Toxicol Pharmacol 40:305-311. https://doi.org/10. 1016/j.yrtph.2004.07.008

Gulia S, Nagendra SMS, Khare M, Khanna I (2015) Urban air quality management - a review. Atmos Pollut Res 6:286-304. https://doi. org/10.5094/APR.2015.033

Hjortenkrans DT, Bergback BG, Haggerud AV (2007) Metal emissions from brake linings and tires: case studies of Stockholm, Sweden 1995/1998 and 2005. Environ Sci Technol 41:5224-5230. https:// doi.org/10.1021/es070198o

Hsieh LT, Yang HH, Chen HW (2006) Ambient BTEX and MTBE in the neighborhoods of different industrial parks in Southern Taiwan. J Hazard Mater 128:106-115. https://doi.org/10.1016/j.jhazmat. 2005.08 .001

HYSPLIT (2019) https://www.ready.noaa.gov/HYSPLIT.php. Accessed 15 August 2019

International Agency for Research on Cancer (IARC) (2018) Agents classified by the IARC monographs, volumes 1-124. https:// monographs.iarc.fr/agents-classified-by-the-iarc/. Accessed 10 December 2018

Jia C, Foran J (2013) Air toxics concentrations, source identification, and health risks: An air pollution hot spot in southwest Memphis, TN. Atmos Environ 81:112-116. https://doi.org/10.1016/j.atmosenv. 2013.09.006

Khalili NR, Sceff PA, Holsen TM (1995) PAH source fingerprints for coke ovens, diesel and, gasoline engines, highway tunnels, and wood combustion emissions. Atmos Environ 29:533-542. https:// doi.org/10.1016/1352-2310(94)00275-P

Kim IS, Lee JY, Kim YP (2013) Impact of polycyclic aromatic hydrocarbons emissions from North Korea to the air quality in the Seoul Metropolitan Area, South Korea. Atmos Environ 70:159-165. https://doi.org/10.1016/j.atmosenv.2012.12.040

Kim MJ, Seo YK, Kim JH, Baek SO (2020) Impact of industrial activities on atmospheric volatile organic compounds in Sihwa-Banwol, the largest industrial area in South Korea. Environ Sci Pollut. Res 27: 28912-28930. https://doi.org/10.1007/s11356-020-09217-x

Kim YP, Lee G, Emmons L, Park R (2018) Preface to a special issue "Megacity Air Pollution Studies (MAPS)". Aerosol and Air Qual Res 18:I-IV. https://doi.org/10.4209/aaqr.2018.09.MAPS

Kim YP, Lee G (2018) Trend of air quality in Seoul: Policy and science. Aerosol Air Qual Res 18:2141-2156. https://doi.org/10.4209/aaqr. 2018.03.0081

Larsen RK, Baker JE (2003) Source apportionment of polycyclic aromatic hydrocarbons in the urban atmosphere: A comparison of three methods. Environ Sci Technol 37:1873-1881. https://doi.org/10. 1021/es0206184

Lee JY, Kim YP, Kang CH (2011) Characteristics of the ambient particulate PAHs at Seoul, a mega city of Northeast Asia in comparison with the characteristics of a background site. Atmos. Res 99:50-56. https://doi.org/10.1016/j.atmosres.2010.08.029

Lee JY, Kim YP, Kang CH, Ghim YS, Kaneyasu N (2006) Temporal trend and long-range transport of particulate polycyclic aromatic hydrocarbons at Gosan in the northeast Asia between 2001 and 2004. J Geophy Res 111:D11303. https://doi.org/10.1029/ 2005JD006537

Li Z, Porter EN, Sjödin A, Needham LL, Lee S, Russell AG, Mulholland JA (2009) Characterization of $\mathrm{PM}_{2.5}$-bound polycyclic aromatic hydrocarbons in Atlanta-Seasonal variations at urban, suburban, and rural ambient air monitoring sites. Atmos Environ 43:4187-4193. https://doi.org/10.1016/j.atmosenv.2009.05.031

Liu Y, Yu Y, Liu M, Lu M, Ge R, Li S, Liu X, Dong W, Qadeer A (2018) Characterization and source identification of PM2.5-bound polycyclic aromatic hydrocarbons (PAHs) in different seasons from Shanghai, China. Sci. Total Environ. 644:725-735. https://doi.org/ 10.1016/j.scitotenv.2018.07.049

Miguel AH, Krichstetter TW, Harley RA, Hering SV (1998) On-road emissions of particulate polycyclic aromatic hydrocarbons and black carbon from gasoline and diesel vehicles. Environ Sci Technol 32: 450-455. https://doi.org/10.1021/es970566w

Mishra N, Ayoko GA, Morawska L (2016) Atmospheric polycyclic aromatic hydrocarbons in the urban environment: occurrence, toxicity and source apportionment. Environ Pollut 208:110-117. https://doi. org/10.1016/j.envpol.2015.08.015

Na GS, Kim YP (2001) Seasonal characteristics of ambient volatile organic compounds in Seoul, Korea. Atmos Environ 35:2603-2614. https://doi.org/10.1016/S1352-2310(00)00464-7

$\mathrm{Na}$ K, Kim YP, Moon I et al (2002) Seasonal variation of $\mathrm{C}_{2}-\mathrm{C}_{9}$ hydrocarbons concentrations and compositions emitted from motor vehicles in a Seoul tunnel. Atmos Environ 36:1969-1978. https://doi. org/10.1016/S1352-2310(02)00149-8

Napier F, Arcy BD, Jefferies C (2008) A review of vehicle related metals and polycyclic aromatic hydrocarbons in the UK environment. Desalination 226:143-150. https://doi.org/10.1016/j.desal.2007.02. 104

Park MB, Lee TJ, Lee ES, Kim DS (2019) Enhancing source identification of hourly PM2.5 data in Seoul based on a dataset segmentation scheme by positive matrix factorization (PMF). Atmos Pollut Res 10:1042-1059. https://doi.org/10.1016/j.apr.2019.01.013

Parrish DD, Zhu T (2009) Clean air for megacities. Science 326:674 -675. https://doi.org/10.1126/science. 1176064

Patrick DR (1994) The definition of toxic air pollutants. In: Patrick DR (ed) Toxic air pollution handbook. Van Nostrand Reinhold, New York, pp 16-18

Ramírez N, Cuadras A, Rovira E et al (2012) Chronic risk assessment of exposure to volatile organic compounds in the atmosphere near the largest Mediterranean industrial site. Environ Int 39:200-209. https://doi.org/10.1016/j.envint.2011.11.002

Ravindra K, Sokhi R, Van Grieken R (2008) Atmospheric polycyclic aromatic hydrocarbons: Source attribution, emission factors and regulation. Atmos Environ 42:2895-2921. https://doi.org/10.1016/j. atmosenv.2007.12.010

Samet JM, Gruskin S (2015) Air pollution, health, and human rights. Lancet Respir Med 3:98-100. https://doi.org/10.1016/S22132600(14)70145-6

Schauer JJ, Kleeman MJ, Cass GR, Simoneit BRT (2002) Measurement of Emissions from Air Pollution Sources. 5. $\mathrm{C}_{1}-\mathrm{C}_{32}$ Organic Compounds from Gasoline-Powered Motor Vehicles. Environ Sci Technol 36:1169-1180. https://doi.org/10.1021/es0108077

Scheffe RD, Strum M, Phillips SB, Thurman J, Eyth A, Fudge S, Morris M, Palma T, Cook R (2016) Hybrid modeling approach to estimate exposures of hazardous air pollutants for the National air Toxics Assessment. Environ Sci Technol 50:12356-12364. https://doi. org/10.1021/acs.est.6b04752

Seo YK, Suvarapu LN, Baek SO (2014) Characterization of odorous compounds (VOC and Carbonyl Compounds) in the ambient air of Yeosu and Gwangyang, large industrial areas of South Korea. Sci World J 2014:824301-824318. https://doi.org/10.1155/2014/ 824301 
Simcik MF, Eisenreich SJ, Lioy PJ (1999) Source apportionment and source/sink relationships of PAHs in the coastal atmosphere of Chicago and Lake Michigan. Atmos Environ 33:5071-5079. https://doi.org/10.1016/S1352-2310(99)00233-2

Taghvaee S, Sowlat MH, Hassanvand MS, Yunesian M, Naddafi K, Sioutas C (2018) Source-specific lung cancer risk assessment of ambient PM 2.5-bound polycyclic aromatic hydrocarbons in central Tehran. Environ Int 120:321-332. https://doi.org/10.1016/j.envint. 2018.08.003

Thang PQ, Kim SJ, Lee SJ, Ye J, Seo YK, Baek SO, Choi SD (2019) Seasonal characteristics of particulate polycyclic aromatic hydrocarbons (PAHs) in a petrochemical and oil refinery industrial area on the west coast of South Korea. Atmos Environ 198:398-406. https:// doi.org/10.1016/j.atmosenv.2018.11.008

Tobiszewski M, Namieśnik J (2012) PAH diagnostic ratios for the identification of pollution emission sources. Environ Pollut 162:110 119. https://doi.org/10.1016/j.envpol.2011.10.025

Tsai PJ, Young LH, Hwang BF, Lin MY, Chen YC (2020) Source and health risk apportionment for $\mathrm{PM}_{2.5}$ collected in Sha-Lu area, Taiwan. Atmos Pollut Res 11:851-858. https://doi.org/10.1016/j. apr.2020.01.013

USEPA (1997) Health Effects Assessment Summary Tables (FY 1997 update). Office of Research and Development. USEPA, Washington, DC

USEPA (2006) Standard Operating Procedure for the Determination of Hexavalent Chromium in Ambient Air Analyzed by Ion Chromatography (IC), Office of Air Quality Planning and Standards. USEPA, Research Triangle Park, NC

USEPA (2009) Risk assessment guidance for superfund volume I: human health evaluation manual. Office of Superfund Remediation and Technology Innovation. USEPA, Washington, DC

USEPA (2014) EPA positive matrix factorization (PMF) 5.0 fundamentals and user guide. Office of Research and Development, USEPA, Washington, DC

USEPA (2016a) Definition and procedure for the determination of the method detection limit, revision:2 https://www.epa.gov/sites/ production/files/2016-12/documents/mdl-procedure_rev2_12-132016.pdf.

USEPA (2016b) Trichloroethylene. https://www.epa.gov/sites/ production/files/2016-09/documents/trichloroethylene.pdf.

USEPA (2017) Urban air toxics.

USEPA (2018a) Dose-response assessment for assessing health risks associated with exposure to hazardous air pollutants. https://www.epa. gov/fera/dose-response-assessment-assessing-health-risksassociated-exposure-hazardous-air-pollutants.

USEPA (2018b) Integrated Risk Information System Assessments. https://cfpub.epa.gov/ncea/iris_drafts/atoz.cfm?list_type=alpha. Accessed 15 December, 2018

USEPA (2018c) Provisional peer-reviewed toxicity values (PPRTVs) assessments. https://www.epa.gov/pprtv/provisional-peerreviewed-toxicity-values-pprtvs-assessments.

USEPA (2019) What are hazardous air pollutants? https://www.epa.gov/ haps/what-are-hazardous-air-pollutants.
USEPA (2020) National Air Toxics Assessment - NATA Glossary of Terms. https://www.epa.gov/national-air-toxics-assessment/nataglossary-terms\#hq.

Vainiotalo S, Peltonen Y, Pfaffli P (1998) MTBE concentrations in ambient air in the vicinity of service stations. Atmos Environ 32:3503 -3509. https://doi.org/10.1016/S1352-2310(98)00056-9

Vejahati F, Xu Z, Gupta R (2010) Trace elements in coals: association with coal and minerals and their behavior during coal utilization - a review. Fuel 89:904-911. https://doi.org/10.1016/j.fuel.2009.06. 013

Wang F, Lin T, Li Y, Ji T, Ma C, Guo Z (2014) Sources of polycyclic aromatic hydrocarbons in PM2.5 over the East China Sea, a downwind domain of East Asian continental outflow. Atmos Environ 92: 484-492. https://doi.org/10.1016/j.atmosenv.2014.05.003

Wang Q, Liu M, Yu Y, Li Y (2016) Characterization and source apportionment of PM2.5-bound polycyclic aromatic hydrocarbons from Shanghai city, China. Environ Pollut 218:118-128. https://doi.org/ 10.1016/j.envpol.2016.08.037

WHO (2000) Guidelines for Air Quality. WHO, Geneva

Wu CF, Liu LJS, Cullen A, Westberg H, Williamson J (2011) Spatialtemporal and cancer risk assessment of selected hazardous air pollutants in Seattle. Environ Int 37:11-17. https://doi.org/10.1016/j. envint.2010.06.006

Wu CF, Wu SY, Wu YH et al (2009) Cancer risk assessment of selected hazardous air pollutants in Seattle. Environ Int 35:516-522. https:// doi.org/10.1016/j.envint.2008.09.009

Xiang Y, Delbarre H, Sauvage S, Léonardis T, Fourmentin M, Augustin P, Locoge N (2012) Development of a methodology examining the behaviours of VOCs source apportionment with micro-meteorology analysis in an urban and industrial area. Environ Pollut 162:15-28. https://doi.org/10.1016/j.envpol.2011.10.012

Xiong Y, Bari MA, Xing Z, Du K (2020) Ambient volatile organic compounds (VOCs) in two coastal cities in western Canada: Spatiotemporal variation, source apportionment, and health risk assessment. Sci Total Environ 706:135970. https://doi.org/10.1016/j. scitotenv.2019.135970

Yunker MB, Macdonald RW, Vingarzan R, Mitchell RH, Goyette D, Sylvestre S (2002) PAHs in the Fraser River basin: a critical appraisal of PAH ratios as indicators of PAH source and composition. Org Geochem 33:489-515. https://doi.org/10.1016/S0146-6380(02) 00002-5

Zhao W, Hopke PK (2004) Source apportionment for ambient particles in the San Gorgonio wildness. Atmos Environ 38:5901-5910. https:// www.sciencedirect.com/science/article/pii/S135223100400696X

Zhou L, Hopke PK, Zhao W (2009) Source apportionment of airborne particulate matter for the speciation trends network site in Cleveland, OH. J Air Waste Manag Assoc 59:321-331. https://doi.org/10. 3155/1047-3289.59.3.321?needAccess=true

Publisher's note Springer Nature remains neutral with regard to jurisdictional claims in published maps and institutional affiliations. 